\title{
A TALE OF TWO COURTS: LITIGATION IN ALAMEDA AND SAN BENITO COUNTIES*
}

\author{
LAWRENCE M. FRIEDMAN \\ Stanford University \\ ROBERT V. PERCIVAL \\ Stanford University
}

American scholarship has lavished most of its attention on appellate courts, paying little attention to courts on the bottom rungs of the ladder. This is true of studies of both past and present courts. ${ }^{1}$ But the trial court is the court with the most direct contact with the man in the street, for both civil and criminal matters. Here he meets the law face-to-face. And, although federal courts are certainly important, state trial courts handle by far the larger volume of work.

This paper reports on a study of the civil load of two trial courts in California between 1890 and 1970. One court sits in an urban county, the other in a rural county. We tried to measure how the work of these courts changed over time. We expected to find that trial courts have come to do less and less work in settling disputes and that most of their labor is now routine, administrative, cut-and-dried. This hypothesis was confirmed. We also expected to find major differences between the rural and the urban court. But here, it turned out, we were surprised. A common fate overtook both courts; and essentially, our data tell a single story, which holds for city and country alike.

\section{THE FUNCTIONS OF TRIAL COURTS}

The functions of courts ${ }^{2}$ change as their societies change.

- Research on this article was supported by National Science Foundation Grant GS 33821. We wish to thank E. Allen John, Jr., Marilyn Epstein, and Marc Warsowe for their great help with the research on which this article is based; and Richard Danzig, Willard Hurst, and Earl Pomeroy for their valuable comments.

1. There have been exceptions-for example, Francis W. Laurent's study of a century of work of the local courts of Chippewa County, Wisconsin. Francis W. Laurent, The Business of a Trial Court: 100 Years of Cases (1950); Charles Clark and Harry Shulman, A Study of Law Administration in Connecticut (1937).

2. On the functions of trial courts in general, see Lawrence M. Fried- 
American society, over the last century, has undergone massive change; hence we expect some alteration in the work of the courts as well. One of the aims of this study is to investigate changes in such functions. We begin with some brief remarks about dispute settlement, one of the basic functions of courts.

\section{A. Dispute Settlement}

Dispute settlement-the resolution of genuine differences between parties ${ }^{3}$ is the function that most clearly fits the traditional picture of court operations. One thinks of wise King Solomon, confronted by two women each of whom claimed to be the mother of a single child; or the judges among the Barotse, described by Max Gluckman; ${ }^{4}$ or, closer to home, two quarreling neighbors, each claiming title to a piece of land; or a seller suing a buyer who refuses to pay the price of a carload of lumber; or an action for libel and slander. In all these cases, private parties invoke the aid of courts-that is, a strong third party (the judge); backed by the power of the state-in an attempt to resolve disputes with another private party. Sometimes, both parties have agreed between themselves to lay their cases before the judge; more often, perhaps, one party (the plaintiff) forces the other party (the defendant) into court.

Dispute settlement is a broad term, which covers many different kinds of activity. Among courts that settle disputes, we can distinguish two polar types of procedure or attitude. One type emphasizes social harmony. The aim is to end a quarrel, patch up a rift in the social fabric, set things right again within a family or tribe. This style has been observed most notably by anthropologists studying judicial process in less developed societies. In these societies, judges are wise men, elders, respected chiefs; the public eagerly attends trials. Fees are small; procedure is simple and non-technical; there are no "legal" norms and rules, distinct from other norms and rules in society; there are few if any special rules of evidence, and little attention is paid

man, "Trial Courts and Their Work in the Modern World," Jahrbuch für Rechtssoziologie und Rechtstheorie (forthcoming).

This study focusses on two functions: dispute settlement, and routine administration. There are other functions, for example, social control (primarily criminal cases, hence not treated here) and review of governmental actions, where government is defendant in a civil suit. Government plaintiffs appeared in less than $3 \%$ of the cases studied; governmental defendants in only $4 \%$.

3. On the definition of a dispute, see Richard L. Abel, "A Comparative Theory of Dispute Institutions in Society," 8 Law \& Society Review 217, 226-7 (1973).

4. Max Gluckman, The Judicial Process Among the Barotse of Northern Rhodesia (1955). 
to formal legal doctrine. Justice will be swift, and, normally, will be in tune with norms widely shared in the community. ${ }^{5}$

This style of decision making is clearly useful and appropriate in simple societies. It helps keep society on an even keel; conflicts do not get out of hand. Disputes get settled, and at the same time, trials and proceedings serve a kind of educational function; they crystallize and publicize community norms. Public opinion encourages people to bring their troubles to court. Because law is not technical but popular, people understand when to invoke it, and they accept the decisions of the courts as legitimate.

The courts in most modern, Western societies are supposed to represent a different style of decision making. These courts are expensive, technical, and slow, compared to the courts discussed above. Legal norms are not the same as social norms. The law speaks a different language, and, in formal proceedings the layman must use a lawyer as translator and go-between. In this sense, then, justice is far from open. Nor is it "open" in the physical sense. To be sure, there are seats at trials for the public. A sensational murder trial will draw a crowd; but few people come to an ordinary trial. Judge and jury will deliberate in secret. Rules of evidence screen out "irrelevant" evidence, under rather rigid standards. Western courts often seem primarily interested in determining which party is (legally) right, and which party is (legally) wrong. The search for the "issue" takes priority over the search for the best social solution, the solution that best preserves or restores harmony in human relations.

The reader will note that these two styles of decision making are associated with different types of society. The social harmony style is associated with small, face-to-face, agricultural or hunting societies; the legalistic style with highly technical, urban societies where people deal constantly with strangers. For this reason, the typical dispute which a court must handle will differ in the two types. In a modern, Western case, it is not usual that the parties to the lawsuit stand in some sort of human relationship. Consider the typical automobile accident case. It is a cold-blooded matter, a matter of dollars and cents, brought between strangers. The courts, in fact, have no particular talent for, or interest in developing the expressive, personal aspects of the case, if any. Where cases present such aspects, the court

5. Id., op. cit.; Floyd Fallers, Law Without Precedent (1969); Laura Nader, "Styles of Court Procedure," in Law in Culture and Society (Laura Nader, ed. 1969). 
studiously ignores them, at least in the formal proceedings and in the formal decision. ${ }^{6}$ Rather, the court will seem to strive to narrow the issues, in a "professional" way; the aim is to handle some precise point of law or of fact.

The assumption, furthermore, is that social change will bring about change in the style of a court. ${ }^{7}$ As society moves from a rural, face-to-face mode of life, to a technical, urban mode of life, dispute settlement becomes more "legal." There is, in short, a rather vague hypothesis that predicts style of court from certain economic, social, and demographic facts. Dispute settlement in a big city court will be more legal, and less "social" than in a rural court.

\section{B. Routine Administration}

The idea of dispute settlement is strong in the imagery of courts. But courts perform other functions, too. One of these we will call routine administration. A matter is routine when a court has no disputed question of law or fact to decide. Routine administration means the processing or approving of undisputed matters. Courts make and keep records, register formalities, stamp their approval on claims or on changes of status; they handle uncontested divorces; render judgment in cases of petty debt; probate uncontested wills; handle petitions for change of name. In these matters there is almost never any real disputeat least none that comes before the court. When hubsand or wife files for divorce, there has usually been some dispute; but the court does not resolve it. Typically, the parties do not go to court at all, until they have worked matters out and are ready for the rubber stamp. ${ }^{8}$

6. It would, in fact, be improper for a judge, in a lawsuit that Smith brings against Jones, to consider the effect of the suit on their relationship as neighbors, or as brothers-in-law. Some courts-family and juvenile courts-have a mandate to take personal relationships into account. And judges may, in hidden or subconscious ways, react to aspects of a case which strictly speaking they ought not legally consider. Still, there is evidence of the "trained incapacity" of judges to handle expressive, social aspects of cases. See, for example, Rüdiger Lautmann's study of the German judiciary, Justiz -die Stille Gewalt (1972); Richard Danzig, "Toward the Creation of a Complementary, Decentralized System of Criminal Justice," 26 Stan. L. Rev. 1 (1973).

Of course, both pictures (of the Western court, and the court of the simple society) are exaggerations-or, if you will, ideal types. Trial courts in the United States and other countries can and do dispense a kind of justice more tailored to the specific situation of the parties, through informal means-in pre-trial proceedings, for example.

7. See Lawrence M. Friedman, The Legal System: A Social Science Perspective 260 (1975).

8. We should not jump to the conclusion, however, that courts and the doctrine they make have no effect on patterns of out-of-court settle- 
To call these matters routine is not to deny their importance. They may-and do-have an important effect, in the mass; but in the particular case, they are small in size and in consequence. And what the court does hardly fits the usual understanding of adjudication. ${ }^{9}$

Routine administration is not a characteristic of the social harmony courts described by anthropologists. It is a modern, Western phenomenon. Societies that are bureaucratic and busy need this kind of formalization far more than hunters and gatherers do. We would expect to find this function becoming more frequent as we approach the present day, and we would expect it to correlate closely with urban and industrial growth. Of our two courts, one is urban, the other is not. The study covers a period of time (1890 to 1970) in which Alameda County urbanized and industrialized more rapidly and profoundly than San Benito. We expect, then, to find great differences in decision-making style, and in the functions performed by the courts. We should see these differences already in 1890 , and by 1970 they should be even clearer.

\section{QUANTITATIVE LNDICATORS OF COURT FUNCTIONS}

How can we measure the functions performed by courts? Some inferences arise from the type of cases courts handle, but this is not terribly reliable. A property case, for example, may require the court to resolve a hotly-contested dispute; a contract case may lay bare complex commercial controversy; on the other hand, many "property" or "contract" cases are simply routine. Divorce and tort cases, too, can be bitterly contested, though usually they are not. The procedural history and outcome of cases may be more reliable indicators. Of cases filed, how many ac-

ment. "The law" that a court is likely to apply is an important factor in the bargaining that takes place in settlement of auto accident cases, for example. See Alfred F. Conard et al., Automobile Accident Costs and Payments (1964); H. Laurence Ross, Settled Out of Court: The Social Process of Insurance Claims Adjustment (1970). Compare Galanter's concept of the "appended" settlement system, that is, a dispute settlement system, which though unofficial is "normatively and institutionally appended to the of ficial system." He gives settlement of auto injuries as an example. Marc Galanter, "Why the 'Haves' Come Out Ahead: Speculations on the Limits of Legal Change," 9 Law \& Society Review 95, 126 (1974).

9. Of course, sometimes, even in routine matters, a serious issue needing exceptional training and skill to handle may abruptly arise. Most probate proceedings are routine; but once in a while a will is contested or a claim disputed. Arguably the judge must stand by, like a doctor at a hospital, in case of emergency. Many uncontested, routine cases are fossilized forms of what were once areas of more vigorous adjudication: divorce and debt collection, for example. 
tually go to trial, how many are settled out of court or voluntarily dropped? What percentage of cases do plaintiffs win? One might expect plaintiffs to win most cases, even contested cases, since people bring lawsuits when they feel a reasonable hope of prevailing. But by the same token, defendants do not resist when resistance is hopeless. When plaintiffs win in an overwhelming percentage of cases, it is a sign that the cases are routine. Similarly, courts produce formal opinions or findings when they resolve real disputes; rarely when the matter is routine.

It is harder to be precise about the two styles of dispute settlement. The nature of the case and the parties provide some clue. Are the parties relatives, or are they strangers? Is it a family case, or a commercial case? But basically, the presence of the "social harmony" style can only be detected by feel, that is, by careful examination of the files.

The raw materials of the study are the civil casefiles of the Superior Courts in two California counties. These files were sampled at twenty-year intervals from 1890 to 1970 , that is, in $1890,1910,1930,1950$, and 1970. Eighteen-ninety was chosen as the starting point, partly because it was the first census year after the court reform that established the system of Superior Courts. In 1890, California was still a young state, compared to the states of the Eastern seaboard. It was yet to experience its greatest urban growth and industrial development.

\section{THE COUNTIES}

Alameda and San Benito are the two counties of the study. Although their borders are less than fifty miles apart, at opposite ends of the Santa Clara Valley in west-central California, they are profoundly different in demographic character. Alameda County is densely populated, part of a sprawling megalopolis. It fronts on the eastern shore of San Francisco Bay, directly across from San Francisco and its peninsula. The county has an area of 840 square miles, stretching from the Contra Costa foothills on the northeast to the Santa Clara County border on the south. Oakland, the county seat and largest city, is located along San Francisco Bay in the county's northwest corner. From this point, a string of suburb-cities, some with populations over 100,000, now sprawl along freeway paths to the north and south, engulfing the western portion of the county in the Bay Area megalopolis.

San Benito County is bounded on the north by the Pajaro River and the southern edge of Santa Clara County. The county 
extends seventy miles to the south, averaging twenty-five miles in east-west width. Hollister is the county seat and only town of size. It is set in a lowland area at the southern end of the Santa Clara Valley, in the northern part of the county. Nearly everyone in the county lives and works in this area, between the hamlet of Tres Piños eight miles to the southwest and San Juan Bautista, an equal distance to the west. ${ }^{10}$ The rest of the county is mountainous, except for one small lowland area, along the east-central edge of the county. The 5,000-foot high Diablo Mountains dominate the county's landscape in the east and central areas; the Gabilan Range separates the county from Monterey County to the west. Pinnacles National Monument, an area of spectacular rock formations, set aside by President Theodore Roosevelt in 1908, is among the Gabilans.

\section{A. Population}

San Benito County has always been rural and sparsely populated. Its growth rate has been, for California, relatively slow. Its population was 6,412 in 1890 ; in 1970 it was 18,226. Alameda County was already somewhat urban in 1890; two-thirds of its people lived in cities of over 5,000. Alameda grew from 93,864 in 1890 to over a million in 1970 (Table 1). In 1910, over 90\% of Alameda's population lived in urban areas. In 1970, Alameda was virtually all urban $(99 \%)$, by the standards of the United States census.

TABLE 1. POPULATION STATISTICS FOR ALAMEDA AND SAN BENITO COUNTIES

\begin{tabular}{|c|c|c|c|c|c|}
\hline County & 1890 & 1910 & 1930 & 1950 & 1970 \\
\hline \multicolumn{6}{|l|}{ ALAMEDA } \\
\hline $\begin{array}{l}\text { Total population } \\
\text { Percent increase }\end{array}$ & 93,864 & \multirow{2}{*}{$\begin{array}{r}246,131 \\
162.2 \% \\
336.2\end{array}$} & \multirow{2}{*}{$\begin{array}{r}474,883 \\
92.9 \% \\
647.9\end{array}$} & \multirow{2}{*}{$\begin{array}{r}\mathbf{7 4 0 , 3 1 5} \\
\mathbf{5 5 . 9 \%} \\
1,010.0\end{array}$} & \multirow{2}{*}{$\begin{array}{r}1,073,184 \\
45.0 \% \\
1,464.1\end{array}$} \\
\hline $\begin{array}{l}\text { Population density } \\
\text { (/sq. mi.) }\end{array}$ & 133.3 & & & & \\
\hline $\begin{array}{l}\text { Percent urban } \\
\text { Percent rural } \\
\text { Percent black }\end{array}$ & $\begin{array}{r}69.2 \% \\
30.8 \% \\
0.8 \%\end{array}$ & $\begin{array}{r}90.5 \% \\
9.5 \% \\
1.5 \%\end{array}$ & $\begin{array}{r}92.5 \% \\
7.5 \% \\
2.1 \%\end{array}$ & $\begin{array}{r}94.7 \% \\
5.3 \% \\
9.4 \%\end{array}$ & $\begin{array}{r}99.0 \% \\
1.0 \% \\
15.0 \%\end{array}$ \\
\hline AN BENITO & & & & & \\
\hline $\begin{array}{l}\text { otal pop } \\
\text { ercent in }\end{array}$ & 6,412 & $\begin{array}{r}8,041 \\
25.4 \%\end{array}$ & $\begin{array}{l}11,311 \\
40.7 \%\end{array}$ & $\begin{array}{l}14,370 \\
27.0 \%\end{array}$ & $\begin{array}{l}18,226 \\
26.8 \%\end{array}$ \\
\hline $\begin{array}{l}\text { Population density } \\
\text { (/sq. mi.) }\end{array}$ & 6. & & & 10.3 & \\
\hline ercent urban & $0.0 \%$ & . & 33. & 34. & $42.0 \%$ \\
\hline $\begin{array}{l}\text { ercent rural } \\
\text { ercent black }\end{array}$ & $\begin{array}{l}0.0 \% \\
1.09\end{array}$ & $\begin{array}{r}100.0 \% \\
0.9 \%\end{array}$ & $0.4 \%$ & $\begin{array}{r}65.9 \% \\
0.2 \%\end{array}$ & $0.3 \%$ \\
\hline
\end{tabular}

Source: U.S. Census Bureau

10. Ronald L. Chatham, The Geography of San Benito County, California, 2 (1962). 
San Benito is still basically rural. Hollister, the county seat, grew enough to be classified as an urban area by 1930; a third of the county's population lived there. In 1970, Hollister had a population of some 8,000 and contained $42 \%$ of the county's population. No other city in the county was large enough to be called urban, either technically or practically.

Alameda's population is more racially diverse than San Benito's. Oakland has a large black population, mostly added after World War II. More than $15 \%$ of Alameda's population is black; few blacks live in San Benito $(0.3 \%)$. But Spanish was the mother tongue of over $30 \%$ of San Benito's population in $1970 .{ }^{11}$

\section{B. The Economy}

The economies of the counties are markedly different. San Benito's economy revolves around agriculture. In 1890 the county produced over one million dollars in farm products, compared to $\$ 390,000$ in manufactured goods. Alameda County, too, was once a rich agricultural area, but its location also suited it for manufacturing and trade, and these in time predominated. In 1890 Alameda County produced over $\$ 12$-million worth of manufactured goods; its agricultural areas yielded $\$ 2.6$-million. ${ }^{12}$ In $1930,53 \%$ of those employed in San Benito had agricultural jobs; only $4 \%$ of Alameda's workers worked in agriculture. By 1970, agriculture had become less labor-intensive, but it remained the dominant occupation in San Benito. Over $20 \%$ of those emloyed in the county worked on farms. ${ }^{13}$ Only about half of one per cent still worked in agriculture in Alameda. County-wide income statistics also reflect the difference between an urban industrial economy and a farm economy. The per capita income in Alameda in $1970, \$ 3,718$, was $34 \%$ higher than in San Benito $(\$ 2,782) .^{14}$

11. U.S. Department of Commerce, Bureau of the Census, 1970 Census of Population, Vol. I, Characteristics of the Population, Part 6, 1035 (1973).

12. U.S. Department of Interior, Census Office, Report of the Statistics of Agriculture at the Eleventh Census: 1890, 200 (1895); U.S. Department of the Interior, Census Office, Report on Manufacturing Industries in the United States at the Eleventh Census: 1890, Part $1,353,355$ (1895).

13. U.S. Department of Commerce, Bureau of the Census, Fifteenth Census of the United States: 1930, Vol. III, Population, Part 1, 273, 275 (1932); U.S. Department of Commerce, Bureau of the Census, 1970 Census, supra, note 11 at $1048,1050$.

14. U.S. Department of Commerce, 1970 Census, supra, note 11, at 1058, 1060 . 


\section{Historical Development}

Before 1874, the area in San Benito was part of Monterey County. The Gabilan Mountains cut off the residents from access to the county seat on the coast. They put pressure on the legislature which created the new county in 1874. Its western boundary ran along the Gabilan range, the eastern along the Diablo Mountains, after later additions from Fresno and Merced Counties.

The oldest settlement in the county is San Juan Bautista in the northwest corner of the county, where a mission was founded in 1797. The mission was secularized in the early 1830's. Shortly thereafter, the Mexican government made large land grants to settlers. ${ }^{15}$ Fifty people lived in San Juan Bautista at the time of the American takeover. ${ }^{16}$

When adventurers and immigrants began to pour into California, after 1848, a few settled in what is now San Benito County. Patrick Breen, father of the first county judge, arrived with his family in 1848; he ran a hotel. Colonel W. W. Hollister, accompanied by a flock of sheep, left Ohio in 1851, and began a sheep ranch in 1855 in the county. In 1968 fifty farmers formed the San Justo Homestead Association and bought the Colonel's ranch. Hollister, named in honor of the Colonel, became the county seat in $1874 .^{17}$

Cattle ranching dominated the economy until the mid-1860's. In the next decade wheat became the principal crop, then later hay and barley. ${ }^{18}$ In 1873 the San Benito branch of the Southern Pacific railroad was extended from Hollister eight miles south to Tres Piños, and this town became the main agricultural shipping point for the surrounding area.

A shortage of cheap power and water, and distance from population centers, handicapped San Benito County; industry never developed. For a brief period the New Idria Quicksilver Mine, in the southeastern part of the county, produced a significant share of the world's quicksilver. Even today there is little industry, except for some agricultural processing plants. San Benito is less than an hour's drive from the southern flank of the Bay

15. Chatham, supra, note 10, at 137; see also History of San Benito County (1881); Lawrence M. Friedman, "San Benito 1890: Legal Snapshot of a County," 27 Stan. L. Rev. 687 (1975).

16. National Society of Colonial Dames, Counties and Courthouses of California 32-33 (1964).

17. Chatham, supra, note 10 , at 144, n.34.

18. Chatham, supra, note 10 , at $149-53$. 
megalopolis, but, as an observer in 1962 remarked, "In many respects, time has bypassed San Benito County."19

The history of Alameda also begins with a mission-San Jose de Guadalupe, founded in 1797 . The mission, located in the fertile south-central portion of the county, was secularized by 1840 . In the early part of the 19th century, Alameda's land was divided into a number of immense "ranchos," including the great Rancho de San Antonio, granted to Luis Maria Peralta. Peralta died in 1851, and a year later the town of Oakland was incorporated on land once part of his domain. ${ }^{20}$

Alameda County was created in 1853. First Alvarado, then San Leandro was the county seat.21 In 1873 the county seat was moved to Oakland, a port and railroad terminus, already undergoing rapid growth. In 1870 , there were 24,000 people in Alameda County. By 1880, the county's population reached nearly 63,000; over half lived in Oakland. By 1900 the county's population had doubled again, to 130,$197 ; 66,960$ lived in Oakland. This rapid growth has continued until the present, though at a declining rate. Alameda is part of a great metropolitan area, laced with freeways, and stretching all along the bayside half of the county. Oakland is a major metropolis; other cities in the county are also quite sizeable-Berkeley, for example, home of the University of California, and Fremont, site of a General Motors plant, each have more than 100,000 people.

\section{THE STUDY}

As we have mentioned, the basic materials for this study were drawn from civil casefiles of the superior courts of the two counties, for the years 1890,1910,1930, 1950, and 1970. The case load of San Benito is small, and hence every case was examined in each of these years. In Alameda, with its enormous caseloads, a sample had to be taken. One hundred cases were taken at random from the files in 1890, 1910, and 1930. In 1950 and 1970, sufficient cases were taken to represent $2 \%$ of the cases. In all, 1176 cases were included in the study -677 from Alameda and 499 from San Benito.

The table below records the number of cases filed in the two counties, for the years in question, and also gives the case-load per 1,000 population. This last figure is, however, difficult to interpret, because, as we shall see, there are other courts that

19. Chatham, supra, note 10 , at 4.

20. Mildred B. Hoover, Historical Spots in California 23 (1937).

21. Leslie J. Freeman, Historic San Leandro, California 34, 40 (1940). 
handle civil litigation, and the concept of a "case" requires some elucidation, too.

\section{TABLE 2. SUPERIOR COURT CASELOAD PER COUNTY}

\begin{tabular}{|c|c|c|c|c|c|}
\hline & 1890 & 1910 & 1930 & 1950 & 1970 \\
\hline \multicolumn{6}{|l|}{ ALAMEDA } \\
\hline $\begin{array}{l}\text { Cases } \\
\text { Population } \\
\text { Cases per } 1,000 \\
\text { population }\end{array}$ & $\begin{array}{r}716 \\
93,864 \\
7.6\end{array}$ & $\begin{array}{r}3,320 \\
246,131 \\
13.5\end{array}$ & $\begin{array}{r}5,112 \\
474,883 \\
10.8\end{array}$ & $\begin{array}{r}7,049 \\
\mathbf{7 4 0 , 3 1 5} \\
\mathbf{9 . 5}\end{array}$ & $\begin{array}{r}11,811 \\
1,073,184 \\
11.0\end{array}$ \\
\hline \multicolumn{6}{|l|}{ SAN BENITO } \\
\hline $\begin{array}{l}\text { Cases } \\
\text { Population } \\
\text { Cases per 1,000 } \\
\text { population }\end{array}$ & $\begin{array}{r}31 \\
6,412 \\
4.8\end{array}$ & $\begin{array}{r}29 \\
8,041 \\
3.6\end{array}$ & $\begin{array}{r}101 \\
11,311 \\
8.9\end{array}$ & $\begin{array}{r}150 \\
14,370 \\
10.4\end{array}$ & $\begin{array}{r}188 \\
18,226 \\
10.2\end{array}$ \\
\hline
\end{tabular}

Throughout the period, the Superior Courts were not exclusively trial courts. At all times between 1890 and 1970, inferior trial courts functioned in the counties and the Superior Courts had jurisdiction over appeals from certain of these courts. ${ }^{22}$ In all, more than $97 \%$ of the cases in the two courts were original. ${ }^{23}$ Less than $3 \%$ were appeals, and all of these were tried de novo in the Superior Court. ${ }^{24}$ The records of these inferior courts are very incomplete, ${ }^{25}$ and the Superior Court has always had a far broader jurisdiction. ${ }^{26}$ Still, these courts-small claims courts, police courts, municipal courts, justice courts-handle, and have handled, a tremendous volume of work. For example, for the fiscal year 1969-70 (California judicial statistics are gath-

22. Cal. Code Crurl Proc. § 904.2 (appeals from Municipal Courts), § 904.3 (appeals from Justice Courts), $\S 117 j$ (appeals from Small Claims Courts). These statutes providing for such appeals are authorized by Cal. Const. Art. VI \& 11. CaL. Code Civn Proc. $\$ 77$ provides for an appellate department of Superior Courts.

23. In Alameda County: $94.5 \%$ in $1890,96.3 \%$ in $1910,96.0 \%$ in 1930 , $99.3 \%$ in $1950,98.7 \%$ in 1970 . In San Benito County: $93.5 \%$ in $1890,96.7 \%$ in $1910,99.0 \%$ in $1930,100.0 \%$ in 1950 , and $98.7 \%$ in 1970.

24. CaL. Code Crvm Proc. $\S 117 \mathrm{j}$ currently requires a trial de novo when appeals from Small Claims Courts reach the Superior Court. Until 1968, a trial de novo was also required of appeals from Justice Courts by CAL. Code CIVIL Proc. $\S 983$. Section 904.3 which replaced $\S 983$ no longer embodies this requirement.

25. This is most acute for the earliest periods. Sporadic early records do survive; and newspaper accounts add significant information. See Friedman, supra, note 15.

28. Cal. Const. ART. VI $\S \S 10-11$ established Superior Courts as courts of general jurisdiction, with the lower limit on their jurisdiction determined by statutes establishing inferior courts of limited jurisdiction. For the years 1890 and 1910 in our study, the civil jurisdiction of Superior Courts extended to cases where the amount in controversy was $\$ 300$ or more. This jurisdictional floor had been increased to $\$ 2,000$ by 1930 and $\$ 3,000$ by 1950 . The present law, in force in 1970, gives Justice Courts jurisdiction up to \$1,000 (CAL. CoDE CrviL Proc. $\$ 112$ ), and Municipal Courts jurisdiction up to $\$ 5,000$ (CAI. Code Crvil PROC. § 89). Superior Courts have jurisdiction over civil cases where the amount in controversy is $\$ 5,000$ or more. 
ered on this basis), the municipal courts of the state disposed of 424,247 civil cases (not counting parking cases). In the Oakland-Piedmont municipal court (the district is the most populous in Alameda County), there were 8,275 small claims filings, 1,724 tort filings, and 8,652 miscellaneous civil filings. ${ }^{27}$

The presence of these inferior courts, and the fact that jurisdictional limits have changed with the years, means that one cannot compare the caseload of Superior Courts over time as strictly and as rigorously as one would like. Their presence makes it difficult to tell how much the actual functions of the courts have changed between 1890 and 1970. The jurisdictional floor of the Superior Court has gone up over the years from $\$ 300$ to $\$ 3,000$. Claims for small amounts, which once appeared in Superior Court, would now show up in one of the inferior courts. Of course, the value of the dollar has also changed. But even if we converted the jurisdictional floor into constant dollars, the correspondence between the two sets of figures would still be inexact over time. Indeed, the presence of these courts means that our data can not conclusively demonstrate that there are no courts in which genuine "disputes" among ordinary people may be heard, and rather cheaply and efficiently. But other studies suggest that the inferior courts too are not functioning in any way as "people courts." 28 Rather, the existence of these courts solves one of the major mysteries of the data: the disappearance of cases of debt collection. ${ }^{29}$ In California, great numbers of debts are collected through the inferior courts.

Yet there are large debts, and the greater mystery is their disappearance from the records. The mystery of the Superior Courts is not so much the vanishing of individual, middle-class litigant, as the vanishing of the business and corporate litigant. The Supreme Courts were and are the basic, fundamental courts for important cases. Any important case must start there; if, for some rare reason, such a case begins in a municipal court, it will go to the Superior Court on appeal. Yet, as we shall see, where

27. Administrative Office of the California Courts, Annual Report, Judicial Statistics for the Fiscal Year 1969-70 131, 192 (1971).

28. See Beatrice A. Moulton, "The Persecution and Intimidation of the Low Income Litigant as Performed by the Small Claims Courts in California," 21 Stan. L. Rev. 1667 (1969).

29. In England, the county courts, the basic civil courts, function primarily as collection agencies. The defendants are consumers and occasional small tradesmen; the English county court is where a grocer or the owner of a clothing store goes to collect money his customers owe. See, for the history of these courts, Brian Abel-Smith and Robert Stevens, Lawyers and the Courts: A Sociological Study of the English Legal System, 1750-1965, (1967), especially 33-35. 
we might expect a great volume of activity, we find instead a void.

One other possible alternative should be mentioned. The United States is a federal system. Is it not conceivable that important cases are funneled into the federal courts? The federal courts handle cases arising under federal laws; they may also hear cases between residents of different states. ${ }^{30}$ The business world is increasingly interstate; perhaps important business cases overwhelmingly gravitate into federal courts.

There is no doubt that federal courts are an important part of the judicial system, and that the volume of work they do is increasing. This is largely due to the fact that federal regulation is ubiquitous in the 20 th century. It seems extremely doubtful that much ordinary civil litigation has been lost to the federal courts. It is true that patent litigation, labor, anti-trust, and bankruptcy matters, not to mention issues of civil rights and civil liberties, will be brought to federal court. But this still leaves an enormous range of disputes that could or must be centered in state courts. Yet, for 1970, the number of ordinary court cases from Alameda and San Benito counties, filed in federal court, was about $1 \%$ of the number of Superior Court cases in the two counties. $^{31}$ At present, a case whose sole federal basis is diversity of citizenship cannot enter federal court unless the amount in controversy is $\$ 10,000$ or more. In California, municipal courts now may hear cases worth up to $\$ 5,000$; but any ordinary cases of debt or property worth between $\$ 5,000$ and $\$ 10,000$

30. 28 U.S. Code $\S 1332$ (1971).

31. In 1970, of the 2,887 civil cases filed in Federal District Court for the Northern District of California (the district encompassing both Alameda and San Benito counties), only $359(12.4 \%)$ could be classified as ordinary civil litigation of the kind likely to be found in state trial courts. The rest were divided among cases in which the federal government was a party (679) and private cases involving: prisoner petitions (966), marine personal injury (383), antitrust (90), copyright and patent (76), labor suits (57), the Federal Employers Liability Act (1) and unclassified subjects (276). Administrative Office of the U.S. Courts, Annual Report of the Director, 1970, 238-39 (1971).

Although the federal statistics do not indicate the county of origin for these cases, Alameda and San Benito counties accounted for only around one-fifth $(21.7 \%)$ of the population of the Northern District of California in 1970. 28 U.S.C. \$ 84 (1971); Bureau of Census, 1970 Census of Population, General Social and Economic Characteristics, California 380 (1972). Assuming a rough proportionality between population and case filings, Alameda and San Benito counties would account for only 79 ordinary civil cases in federal court in 1970 (21.7\% of 359$)$. Even the inclusion of these counties' share of private unclassified cases would only increase this total to 139 (adding $21.7 \%$ of 276) and many of these additional cases would not represent ordinary civil litigation. When this figure is compared with the approximately 12,000 civil cases in the superior courts of Alameda and San Benito counties in 1970, it is small indeed (around $1 \%)$. 
must be brought to Superior Court; there is no other forum. Hence we should expect to find many cases today in Superior Court that occupy this band of space-with too much at stake for municipal court, too little for federal. These expectations are not met. Indeed, at all times, there existed such a band (though the threshold amounts varied). That cases within the band have virtually disappeared by 1970 , argues against the hypothesis that federal courts have picked up a function state courts were gradually losing.

\section{A. The Docket}

What kind of cases do the two courts hear? How has the docket changed over time? A number of broad trends become apparent upon examining the incidence of types of cases in our study (Tables 3 and 4, Figures 1 and 2).

In both counties the percentage of family and tort cases filed rose dramatically from 1890 to 1970: the proportion of property and contract cases fell quite drastically. The family cases are primarily uncontested divorces in which the court basically does nothing except to stamp its approval on arrangements which the parties have already agreed to before coming to court. Contemporary tort cases generally stem from automobile accidents. At first glance, there seem to be substantial disputes in some of these cases, but the defendant's insurance company will settle almost all of them before they go to trial (Figure 7). Neither in family nor in tort cases do courts often resolve a true "dispute" between two contending parties. And in the family cases, there is not the slightest trace, in either county, of the social harmony mode.

In both counties, contract and property cases were the most frequent kinds of litigation in 1890 . Not by any means were all of these cases contested even then (see Table 5). Property cases fell from around a quarter of all cases in 1890 to less than $4 \%$ of each county's cases in 1970 . In Alameda County in 1890, 57\% of the cases were classified as contract or property. Such cases constituted only $18 \%$ of the 1970 docket, a difference significant at the $.1 \%$ level. The trend appears even more marked in San Benito. Three-fifths of San Benito's 1890 docket were property or contract cases. By 1970, such cases amounted to about one in eight; the difference here too is significant at the $.1 \%$ level. Three of every five cases were routine family matters. Nearly half of all the "cases" in San Benito in 1970 were routine petitions for dissolution of marriage. Corporation or labor cases rarely occur. 


\section{TABLE 3. TYPE OF CASE-ALAMEDA COUNTY}

\begin{tabular}{|c|c|c|c|c|c|c|c|c|c|c|}
\hline \multirow{4}{*}{$\begin{array}{l}\text { ALAMEDA COUNTY } \\
\text { Number of cases } \\
\text { (\% of total) } \\
\text { TYE OF CABE } \\
\text { number }(\%) \\
\text { FAMnY }\end{array}$} & \multicolumn{2}{|r|}{1890} & \multicolumn{2}{|c|}{1910} & \multicolumn{2}{|c|}{1930} & \multicolumn{2}{|c|}{1950} & \multicolumn{2}{|c|}{1970} \\
\hline & \multirow[t]{2}{*}{100} & \multirow[t]{2}{*}{$(14.0 \%)$} & \multirow[t]{2}{*}{100} & \multirow[t]{2}{*}{$(3.0 \%)$} & \multirow[t]{2}{*}{100} & \multirow[t]{2}{*}{$(2.0 \%)$} & \multirow[t]{2}{*}{141} & \multirow[t]{2}{*}{$(2.0 \%)$} & \multirow[t]{2}{*}{236} & \multirow[t]{2}{*}{$(2.0 \%)$} \\
\hline & & & & & & & & & & \\
\hline & 18 & $(18.0)$ & 23 & $(23.0)$ & 20 & $(20.0)$ & 58 & $(41.1)$ & 122 & $(51.7)$ \\
\hline $\begin{array}{l}\text { Divorce or } \\
\text { Annulment }\end{array}$ & 16 & $(16.0)$ & 23 & (23.0) & 18 & (18.0) & 57 & $(40.4)$ & 106 & (44.9) \\
\hline Other Family & 2 & $(2.0)$ & $\mathbf{0}$ & $(0.0)$ & 2 & $(2.0)$ & 1 & $(0.7)$ & 16 & $(6.8)$ \\
\hline CONTRACTS & 33 & $(33.0)$ & $\overline{31}$ & $(31.0)$ & 28 & $(28.0)$ & $\overline{21}$ & $(14.9)$ & 37 & $(\mathbf{1 5 . 7 )}$ \\
\hline Promissory Notes - & 17 & $(17.0)$ & 11 & (11.0) & 10 & $(10.0)$ & 8 & (5.7) & 3 & (1.3) \\
\hline tracts \& Debts - & 6 & $(6.0)$ & $\mathbf{5}$ & $(\mathbf{5 . 0})$ & $\mathbf{0}$ & $(0.0)$ & 3 & (2.1) & 2 & $(0.8)$ \\
\hline $\begin{array}{l}\text { Contracts Between } \\
\text { Merchants }\end{array}$ & 0 & $(0.0)$ & 3 & (3.0) & 3 & (3.0) & 1 & $(0.7)$ & $\mathbf{2}$ & $(0.8)$ \\
\hline Wage Claims ....._- & $\mathbf{0}$ & $(0.0)$ & 3 & (3.0) & 1 & $(1.0)$ & 4 & (2.8) & 2 & $(0.8)$ \\
\hline Chattel Fin. & 0 & $(0.0)$ & 1 & $(1.0)$ & 1 & $(1.0)$ & 0 & $(0.0)$ & 1 & $(0.4)$ \\
\hline Insurance __....... & 0 & $(0.0)$ & 0 & $(0.0)$ & 1 & $(1.0)$ & 0 & $(0.0)$ & $\mathbf{5}$ & (2.1) \\
\hline $\begin{array}{l}\text { Other Contracts } \\
\text { \& Debts }\end{array}$ & 10 & $(10.0)$ & 8 & $(\mathbf{8 . 0 )}$ & 12 & $(12.0)$ & 5 & (3.5) & 22 & (9.3) \\
\hline PROPERTY & $\overline{24}$ & $(24.0)$ & 20 & $(20.0)$ & 11 & $(11.0)$ & 13 & $(9.2)$ & 6 & $(2.3)$ \\
\hline $\begin{array}{l}\text { Land Transfer \& } \\
\text { Marketing }\end{array}$ & 20 & $(20.0)$ & 17 & $(17.0)$ & 5 & $(5.0)$ & 12 & $(8.5)$ & 3 & (1.3) \\
\hline Land Use _-_... & 1 & $(1.0)$ & 1 & $(1.0)$ & 1 & $(1.0)$ & 0 & $(0.0)$ & $\mathbf{0}$ & $(0.0)$ \\
\hline Tenant & 3 & (3.0) & 2 & $(2.0)$ & 3 & $(3.0)$ & 0 & $(0.0)$ & 3 & (1.3) \\
\hline Personal Property & $\mathbf{0}$ & $(0.0)$ & $\mathbf{0}$ & $(0.0)$ & 2 & $(2.0)$ & 1 & $(0.7)$ & 0 & $(0.0)$ \\
\hline TORTS & 6 & $(6.0)$ & 5 & $(5.0)$ & 28 & $(28.0)$ & 32 & (22.7) & 64 & $(27.1)$ \\
\hline Auto Accidents - & 0 & $(0.0)$ & $\mathbf{0}$ & $(0.0)$ & 19 & $(19.0)$ & 23 & $(\mathbf{1 6 . 3 )}$ & 45 & (19.1) \\
\hline $\begin{array}{l}\text { Uner Fersonal } \\
\text { Injury }\end{array}$ & 3 & (3.0) & 4 & $(4.0)$ & 5 & $(5.0)$ & 7 & $(5.0)$ & 15 & (6.4) \\
\hline Other Torts & 3 & $(3.0)$ & 1 & (1.0) & 4 & $(4.0)$ & 2 & $(1.4)$ & 4 & (1.7) \\
\hline GOVERNMENTAL & 13 & $(13.0)$ & $1 \overline{8}$ & $(\mathbf{1 8 . 0 )}$ & 8 & $(8.0)$ & 7 & $(5.0)$ & 3 & $\overline{(1,3)}$ \\
\hline $\begin{array}{l}\text { Municipal } \\
\text { Assessments }\end{array}$ & 7 & $(7.0)$ & 15 & $(15.0)$ & 0 & $(0.0)$ & 0 & $(0.0)$ & $\mathbf{0}$ & $(0.0)$ \\
\hline $\begin{array}{l}\text { State-Local } \\
\text { Govt. Admin. }\end{array}$ & 5 & $(5.0)$ & 2 & $(2.0)$ & 3 & $(3.0)$ & 4 & $(2.8)$ & 1 & $(0.4)$ \\
\hline Nuisance & $\mathbf{0}$ & $(0.0)$ & 0 & $(0.0)$ & 3 & $(3.0)$ & 0 & $(0.0)$ & $\mathbf{0}$ & $(0.0)$ \\
\hline Condemnation -- & 1 & $(1.0)$ & 1 & $(1.0)$ & $\mathbf{2}$ & $(2.0)$ & 3 & (2.1) & 2 & (0.8) \\
\hline CORPORATIONS & & & & & & & & & & \\
\hline 8 LABOR & 1 & $(1.0)$ & 2 & $(2.0)$ & 2 & $(2.0)$ & 5 & $(3.5)$ & 3 & (1.3) \\
\hline $\begin{array}{l}\text { Business } \\
\text { Associations }\end{array}$ & $\mathbf{1}$ & $(1.0)$ & $\mathbf{2}$ & $(2.0)$ & 1 & $(1.0)$ & 2 & (1.4) & 2 & (0.8) \\
\hline $\begin{array}{l}\text { Non-Business } \\
\text { Associations }\end{array}$ & $\mathbf{0}$ & $(0.0)$ & $\mathbf{0}$ & $(0.0)$ & 0 & $(0.0)$ & 0 & $(0.0)$ & 0 & $(0.0)$ \\
\hline $\begin{array}{l}\text { Competition/Trade } \\
\text { Reg./Labor }\end{array}$ & 0 & $(0.0)$ & 0 & $(0.0)$ & 1 & (1.0) & 3 & $(2.1)$ & 1 & $(0.4)$ \\
\hline $\begin{array}{l}\text { PERSONAL, } \\
\text { FINANCE/ }\end{array}$ & & & & & & & & & & \\
\hline INHERITANCE & 2 & (2.0) & 1 & $(1.0)$ & 2 & $(2.0)$ & 3 & $(2.1)$ & 0 & $(0.0)$ \\
\hline Insolvency Petition & 2 & $(2.0)$ & 0 & $(0.0)$ & 0 & $(0.0)$ & 0 & $(0.0)$ & $\mathbf{0}$ & $(0.0)$ \\
\hline $\begin{array}{l}\text { Succession/ } \\
\text { Fiduciary }\end{array}$ & $\mathbf{0}$ & $(0.0)$ & 1 & $(1.0)$ & 2 & (2.0) & 3 & (2.1) & 0 & $(0.0)$ \\
\hline MASCBLLANEOUS -- & 3 & $(3.0)$ & 0 & $(0.0)$ & 1 & $(1.0)$ & 2 & $(1.4)$ & 1 & $(0.4)$ \\
\hline $\begin{array}{l}\text { Enforcement of } \\
\text { Judgments .......... } \\
\text { Miscellaneous }\end{array}$ & $\begin{array}{l}\mathbf{2} \\
\mathbf{1}\end{array}$ & $\begin{array}{l}(2.0) \\
(1.0)\end{array}$ & $\begin{array}{l}0 \\
0\end{array}$ & $\begin{array}{l}(0.0) \\
(0.0)\end{array}$ & $\begin{array}{l}0 \\
1\end{array}$ & $\begin{array}{l}(0.0) \\
(1.0)\end{array}$ & $\begin{array}{l}0 \\
2\end{array}$ & $\begin{array}{l}(0.0) \\
(1.4)\end{array}$ & $\begin{array}{l}1 \\
0\end{array}$ & $\begin{array}{l}(0.4) \\
(0.0)\end{array}$ \\
\hline
\end{tabular}




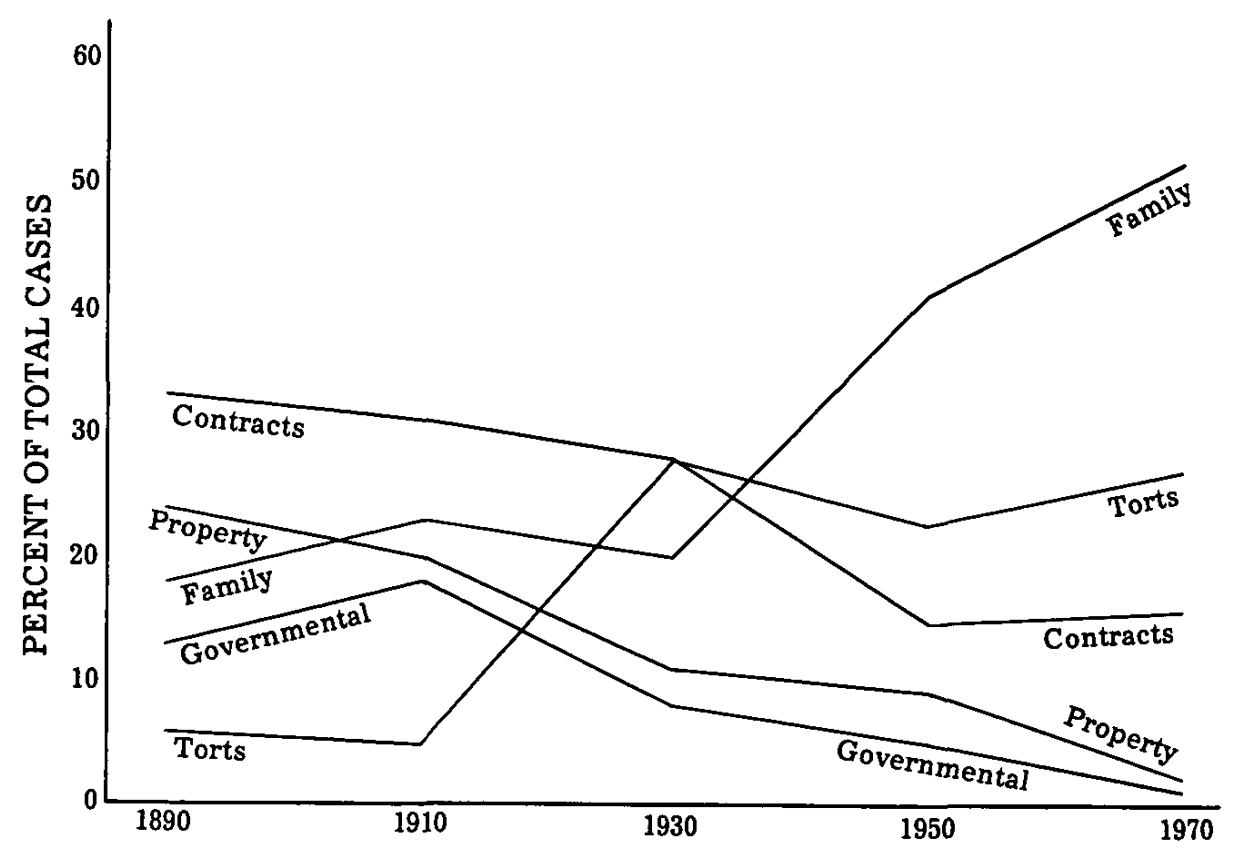

Figure 1. Type of Case-Alameda County (1890-1970)

TABLE 4. TYPE OF CASE_SAN BENITO COUNTY

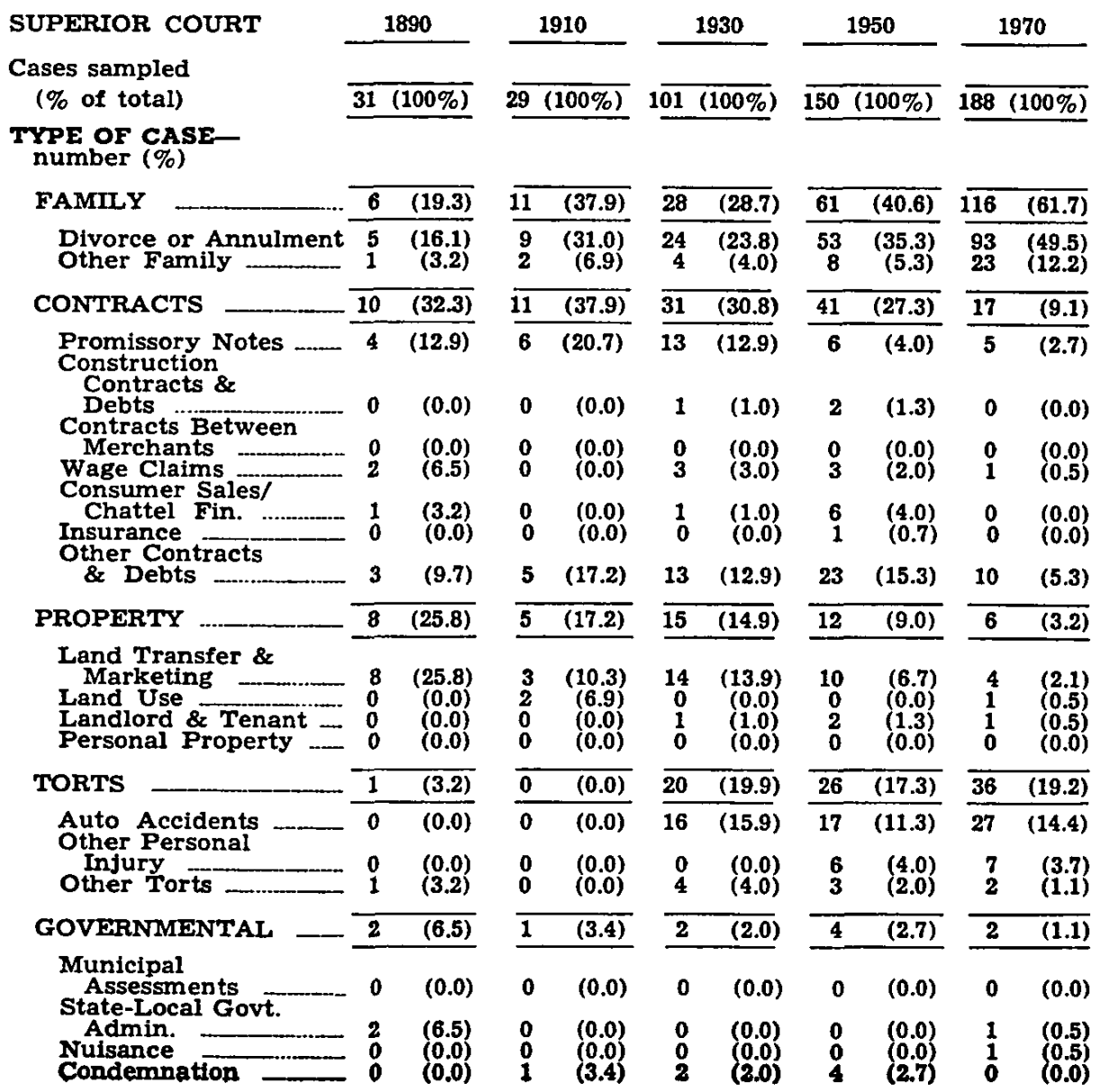




\begin{tabular}{|c|c|c|c|c|c|c|c|c|c|c|}
\hline \multirow{2}{*}{$\begin{array}{l}\text { CORPORATIONS } \\
\text { \& LABOR }\end{array}$} & \multirow[b]{2}{*}{1} & \multirow[b]{2}{*}{ (3.2) } & & \multirow[b]{2}{*}{ (3.4) } & \multirow[b]{2}{*}{2} & \multirow[b]{2}{*}{$\overline{(2.0)}$} & \multirow[b]{2}{*}{1} & \multirow[b]{2}{*}{ (0.7) } & \multirow[b]{2}{*}{6} & \multirow[b]{2}{*}{ (3.2) } \\
\hline & & & & & & & & & & \\
\hline $\begin{array}{l}\text { Buslness } \\
\text { Associations }\end{array}$ & 1 & (3.2) & 1 & (3.4) & 2 & $(2.0)$ & 1 & (0.7) & 0 & $(0.0)$ \\
\hline Associations & 0 & $(0.0)$ & 0 & $(0.0)$ & 0 & $(0.0)$ & 0 & $(0.0)$ & 1 & (0.5) \\
\hline $\begin{array}{l}\text { Competition/Trade } \\
\text { Reg/Labor }\end{array}$ & 0 & $(0.0)$ & $\mathbf{0}$ & $(0.0)$ & 0 & $(0.0)$ & 0 & $(0.0)$ & 5 & (2.7) \\
\hline PERSON FINANCE/ & & & & & & & & & & \\
\hline INHERITANCE & 1 & $(3.2)$ & $\mathbf{0}$ & $(0.0)$ & 0 & $\overline{(0.0)}$ & 2 & (1.3) & 0 & $(0.0)$ \\
\hline $\begin{array}{l}\text { Insolvency Petition } \\
\text { Succession/Fiduciary }\end{array}$ & 1 & $\begin{array}{l}(0.0) \\
(3.2)\end{array}$ & & $\begin{array}{l}(0.0) \\
(0.0)\end{array}$ & $\begin{array}{l}0 \\
0\end{array}$ & $\begin{array}{l}(0.0) \\
(0.0)\end{array}$ & $\begin{array}{l}\mathbf{0} \\
\mathbf{2}\end{array}$ & $\begin{array}{l}(0.0) \\
(1.3)\end{array}$ & 0 & $\begin{array}{l}(0.0) \\
(0.0)\end{array}$ \\
\hline MISCELLANEOUS & 2 & $(6.5)$ & $v$ & $(0.0)$ & 3 & $\overline{(3.0)}$ & 2 & (1.3) & 2 & $(1.1)$ \\
\hline $\begin{array}{l}\text { Enforcement of } \\
\text { Judgments } \\
\text { Miscellaneous }\end{array}$ & $\begin{array}{l}\mathbf{0} \\
\mathbf{2}\end{array}$ & $\begin{array}{l}(0.0) \\
(6.5)\end{array}$ & a & $\begin{array}{l}(0.0) \\
(0.0)\end{array}$ & $\begin{array}{l}3 \\
0\end{array}$ & $\begin{array}{l}(3.0) \\
(0.0)\end{array}$ & $\begin{array}{l}0 \\
2\end{array}$ & $\begin{array}{l}(0.0) \\
(1.3)\end{array}$ & $\begin{array}{l}1 \\
1\end{array}$ & $\begin{array}{l}(0.5) \\
(0.5)\end{array}$ \\
\hline UNKNOWN & $\mathbf{0}$ & $(0.0)$ & $\mathbf{0}$ & $(0.0)$ & $\mathbf{0}$ & $(0.0)$ & 1 & (0.7) & 3 & (1.6) \\
\hline
\end{tabular}

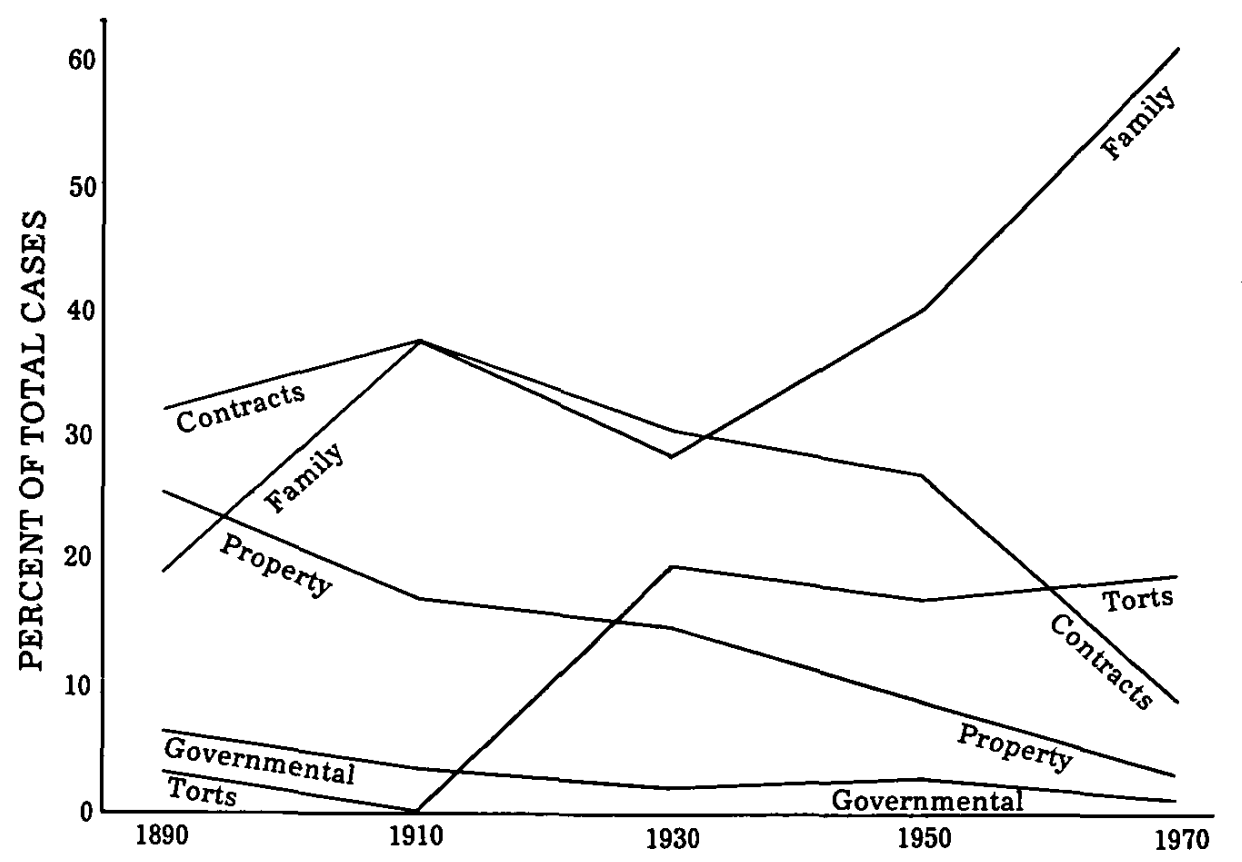

Figure 2. Type of Case-San Benito County (1890-1970)

Yet we feel confident that, as the economy develops, the volume of private transactions which use legal forms, or which take account of legal rules and processes, rises tremendously. Contracts are made, corporations formed, and property changes hands. The law (statutes, decisions of appellate courts, administrative proceedings) may significantly affect the form and legitimacy of these private transactions; yet in both counties we find a decline in formal resort to courts, to adjudicate disputes arising out of legal transactions. Surprisingly, San Benito (rural, non-industrial) and Alameda (urban, industrial) differ not at all in these regards. In both, the incidence of cases of economic disputes has fallen off, and the incidence of routine cases has risen. 
TABLE 5. PERCENT OF CASES TRIED

\begin{tabular}{|c|c|c|c|c|c|}
\hline & 1890 & $\underline{1910}$ & 1930 & 1950 & 1970 \\
\hline \multicolumn{6}{|l|}{ ALAMEDA } \\
\hline $\begin{array}{l}\text { All cases } \\
\text { Contracts } \\
\text { Property }\end{array}$ & $\begin{array}{l}36.0 \\
30.3 \\
54.2\end{array}$ & $\begin{array}{l}25.0 \\
22.6 \\
55.0\end{array}$ & $\begin{array}{l}48.0 \\
57.1 \\
63.6\end{array}$ & $\begin{array}{l}29.1 \\
19.0 \\
53.8\end{array}$ & \\
\hline \multicolumn{6}{|c|}{ SAN BENITO } \\
\hline $\begin{array}{l}\text { All cases } \\
\text { Contracts } \\
\text { Property }\end{array}$ & $\begin{array}{l}25.8 \\
40.0 \\
12.5\end{array}$ & $\begin{array}{r}37.9 \\
18.2 \\
100.0\end{array}$ & $\begin{array}{l}19.8 \\
19.4 \\
33.3\end{array}$ & $\begin{array}{l}20.0 \\
17.1 \\
33.3\end{array}$ & \\
\hline
\end{tabular}

TABLE 6. CASE DISPOSITION-ALAMEDA COUNTY

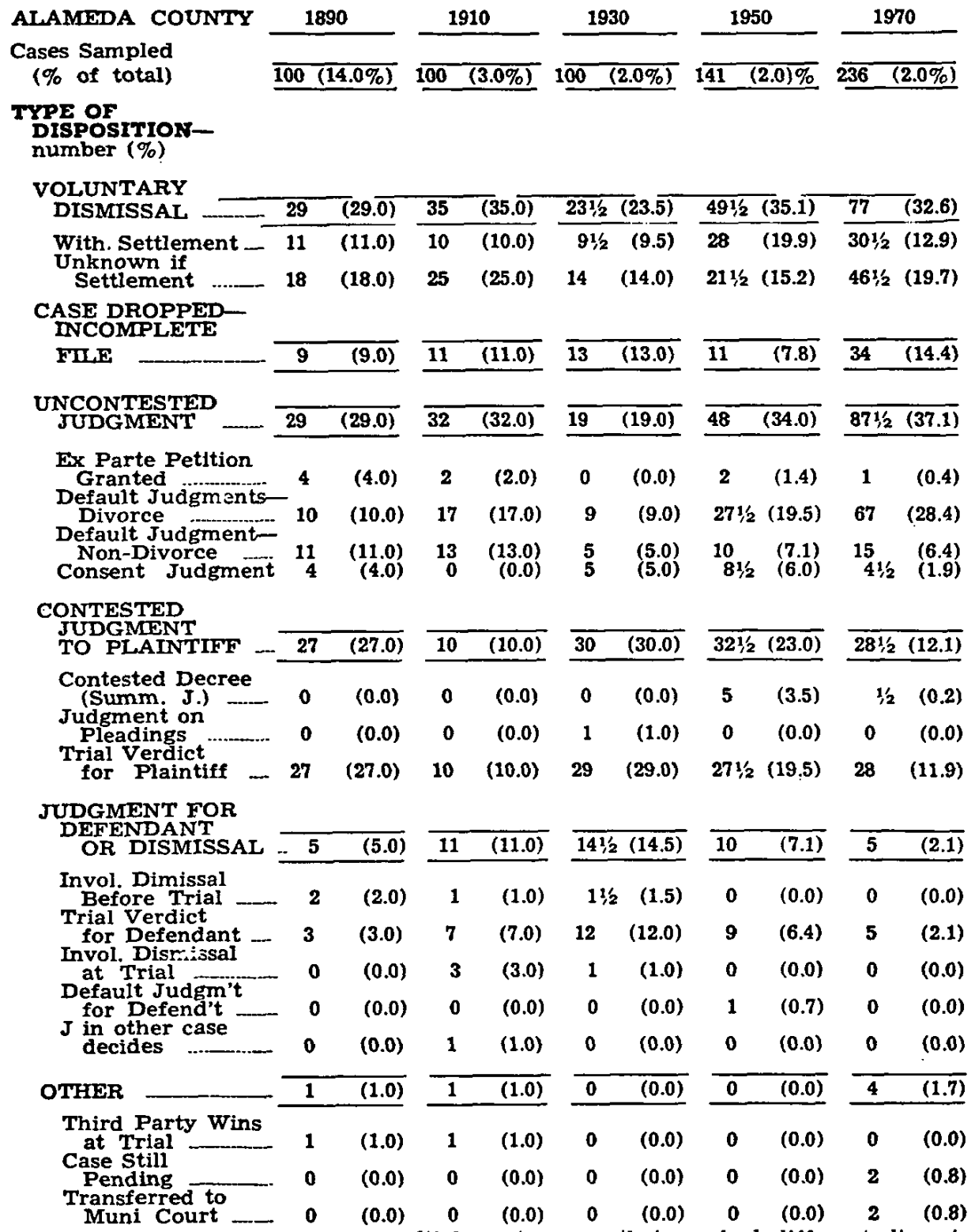

(Totals ending in $1 / 2$ represent multiple-party cases that reached different dispositions relative to two different parties defendant.) 


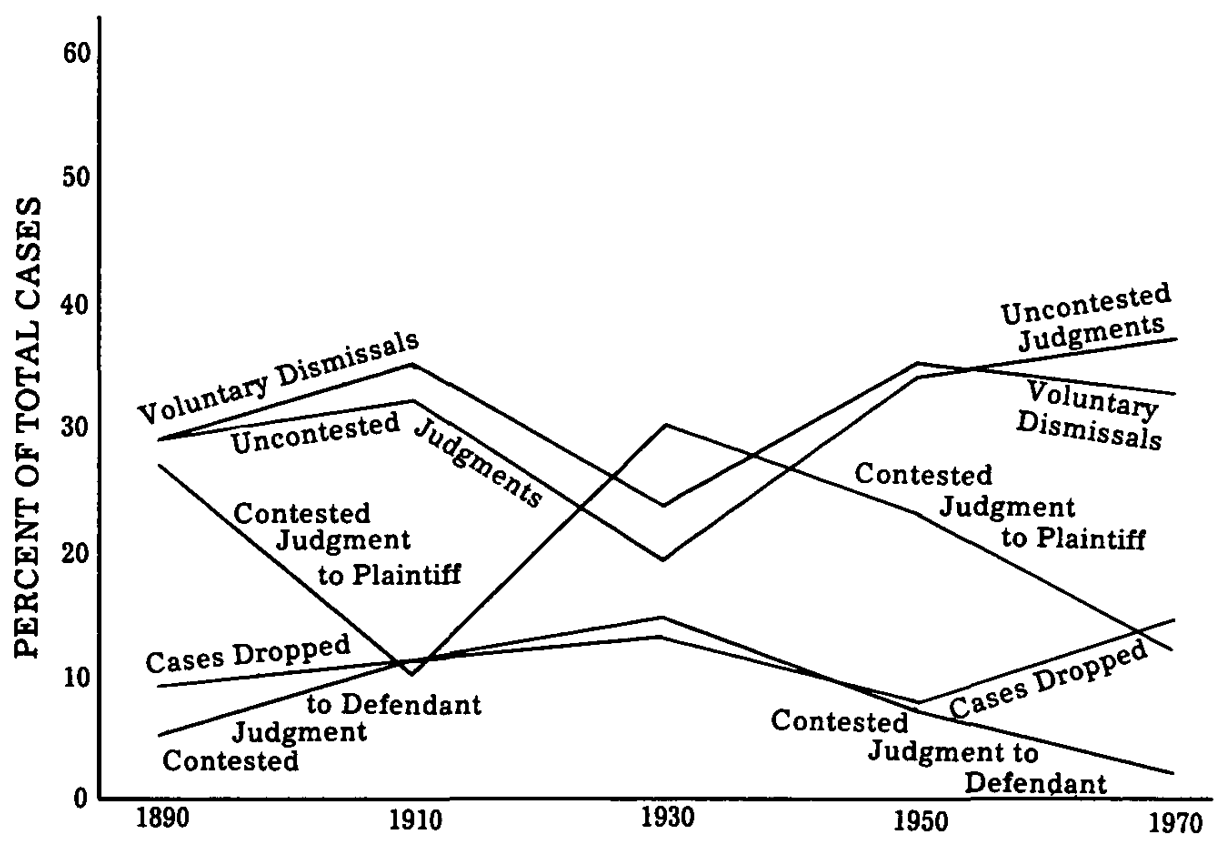

Figure 3. Case Disposition-Alameda County (1890-1970)

TABLE 7. CASE DISPOSITION-SAN BENITO COUNTY

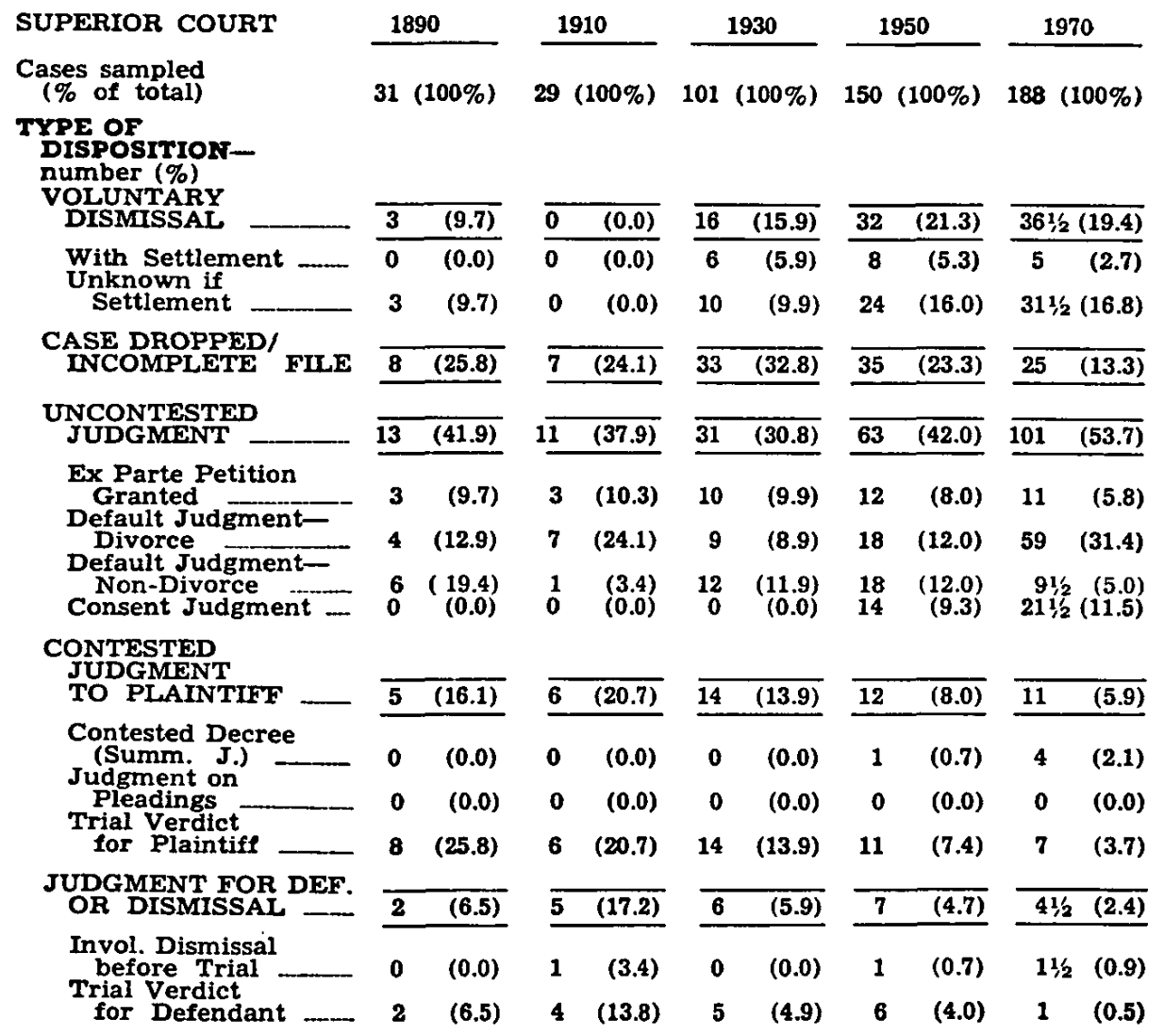




\begin{tabular}{|c|c|c|c|c|c|c|c|c|c|c|}
\hline $\begin{array}{l}\text { Invol. Dismissal } \\
\text { at Trial } \\
\text { Default Judgment } \\
\text { for Defendant }\end{array}$ & 0 & $\begin{array}{l}(0.0) \\
(0.0)\end{array}$ & $\begin{array}{l}0 \\
0\end{array}$ & $\begin{array}{l}(0.0) \\
(0.0)\end{array}$ & $\begin{array}{l}0 \\
1\end{array}$ & $\begin{array}{l}(0.0) \\
(1.0)\end{array}$ & $\begin{array}{l}0 \\
0\end{array}$ & $\begin{array}{l}(0.0) \\
(0.0)\end{array}$ & 0 & $\begin{array}{l}(1.1) \\
(0.0)\end{array}$ \\
\hline THER & 0 & $\overline{(0.0)}$ & $\overline{\mathbf{0}}$ & $\overline{(0.0)}$ & 1 & $(1.0)$ & 1 & $\overline{(0.7)}$ & 10 & $\overline{(5.3)}$ \\
\hline $\begin{array}{l}\text { Removed to U.S. } \\
\text { Dist. Court } \\
\text { Change of Venue -.. } \\
\text { Indefinite } \\
\text { Continuance }\end{array}$ & $\begin{array}{l}0 \\
0 \\
0\end{array}$ & $\begin{array}{l}(0.0) \\
(0.0) \\
(0.0)\end{array}$ & $\begin{array}{l}0 \\
0 \\
0\end{array}$ & $\begin{array}{l}(0.0) \\
(0.0) \\
(0.0)\end{array}$ & $\begin{array}{l}1 \\
0 \\
0\end{array}$ & $\begin{array}{l}(1.0) \\
(0.0) \\
(0.0)\end{array}$ & $\begin{array}{l}0 \\
1\end{array}$ & $\begin{array}{l}(0.0) \\
(0.7) \\
(0.0)\end{array}$ & $\begin{array}{l}7 \\
3\end{array}$ & $\begin{array}{l}(0.0) \\
(3.7) \\
(1.6)\end{array}$ \\
\hline
\end{tabular}

(Totals ending in $1 / 2$ represent multiple-party cases which reached different dispositions relative to two different parties defendant.)

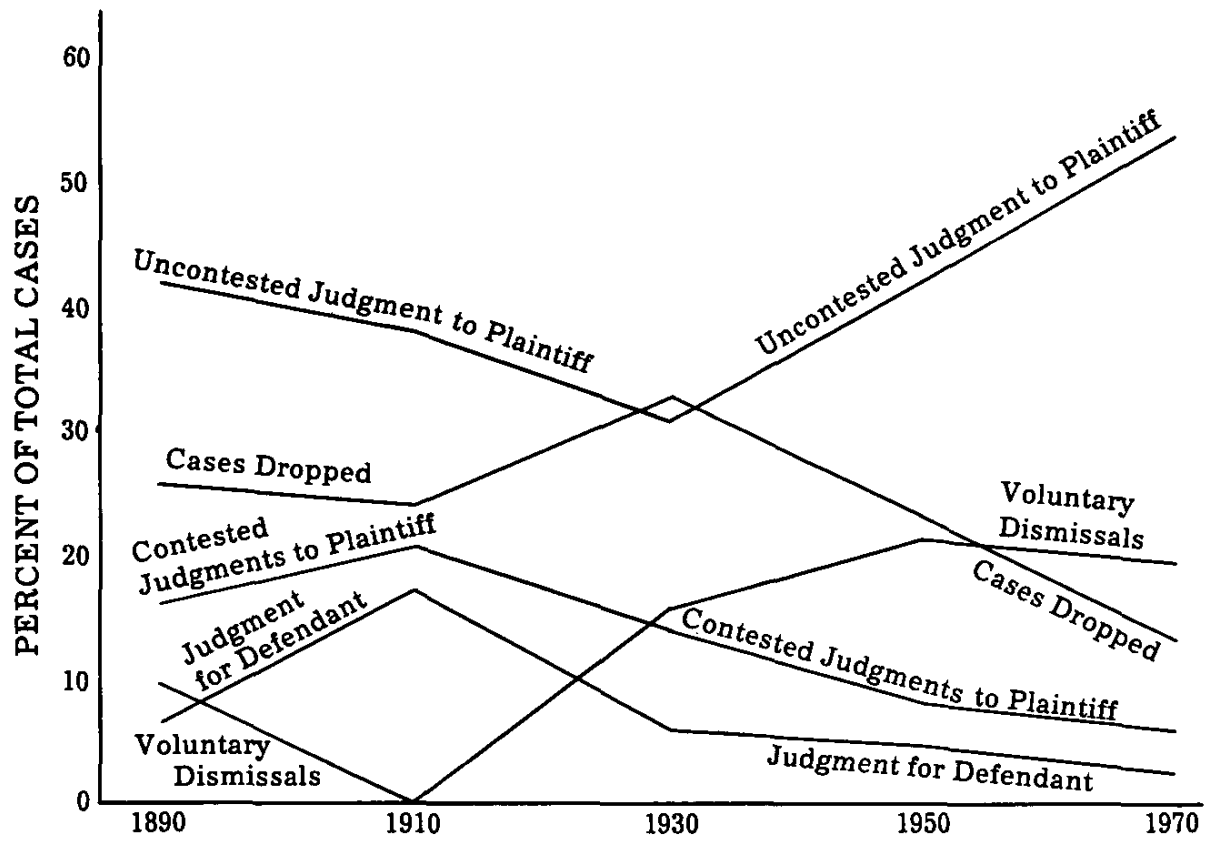

Figure 4. Case Disposition-San Benito County (1890-1970)

\section{B. Case Disposition}

Another indication of the role courts play is provided by examination of how cases are resolved (Tables 6 and 7, Figures 3 and 4). As uncontested judgments-mostly judgments by default-rise, in both counties the percentage of contested judgments for defendants) falls, dropping from $32.0 \%$ to $14.2 \%$ in Alameda (significant at the $.1 \%$ level) and from $22.6 \%$ to $8.3 \%$ in San Benito (although because of the small number of 1890 cases in the sample, this result is not statistically significant). San Benito has a higher incidence of dissolution petitions; here the proportion of cases disposed of by uncontested judgments rises to over half of all cases. This is evidence of the shift toward administration, away from dispute settlement. The trend is equally striking if we take the percentage of judgments which are contested. In Alameda, the proportion of judgments which are uncontested has risen from $47.5 \%$ in 1890 to $71.9 \%$ in 1970 (significant at the .2\% level). In San Benito $86.7 \%$ of the judgments are now uncontested, as opposed to 65\% in 1890 (sig- 
nificant at the $.2 \%$ level). Here, too, Alameda seems, surprisingly enough, less routinized and perfunctory than San Benito, where less than one case in ten is contested.

\section{Proportion of Plaintiff Victories}

We suggested that the percentage of cases which plaintiffs win is an indicator of degree of routinization of judicial process. Where there are genuine disputes, one might still expect plaintiffs to win most of their cases; but not 90 to 95 percent. In Alameda, plaintiffs won $96 \%$ of the judgments in 1970; in San Benito, 97\%. Similar findings have been reported in other jurisdictions. ${ }^{32}$ This too indicates movement towards a routine administrative role. In San Benito, the percentage of plaintiff victories was slimmest in $1910(77 \%)$; in Alameda it was slimmest in $1930(77 \%)$, perhaps indicating a greater dispute-settlement role than in 1890 when the ratio is greatest for Alameda. In Alameda, contested cases were most frequent and voluntary dismissals least frequent in 1930 (44.5\% contested judgments, 23.5\% voluntary dismissals); in San Benito in 1910 (37.9\% contested judgments, $0 \%$ voluntary dismissals).

\section{Percent of Cases Brought to Trial}

One index of dispute settlement is the percentage of cases brought to formal trial. In both counties the incidence of trials has substantially declined between 1890 and 1970 (Table 8, Figure 5). In 1890, more than one out of every three cases filed in Alameda County was brought to trial. Today less than one in six has such a life cycle (a difference significant at the $.1 \%$ level). The trend is also pronounced in San Benito; trial incidence fell from one in four in 1890, to only one of nine today (significant at the 5\% level). Again, this is a strong trend away from dispute settlement; and, again, the incidence of dispute

32. Craig Wanner, "The Public Ordering of Private Relations," Part II, 9 Law \& Society Review 293 (1975). In New Haven and Waterbury Connecticut, in the period roughly between 1919 and 1930 , plaintiffs won $83 \%$ of their cases. Clark and Shulman, supra, note 1, at 41 . See also Marc Galanter, "Why the 'Haves' Come Out Ahead; Speculations on the Limits of Legal Change," 9 Law \& Society Review 95 (1974).

In England, where the county courts have been used as routine debt collection courts, the same disparities appear. For example, in Durham County Court, in a single day, Feb. 13, 1911, there were 111 cases entered on the record books. In only 3 of these was judgment entered for defendant (plaintiffs won 80 ; seven were marked "paid;" in 12, defendant was not served; in eight the case was struck out or withdrawn). Durham County Court, P.R.O. AK2 no. 10. Plaint and Minute Book B 18ff, 1910-11. Aggregate statistics present a similar picture; for example, in $1870,912,795$ cases were entered in county court; 523,340 went to judgment; plaintiffs won 505,744 of these judgments; there were 8,185 non-suits and only 9,411 judgments for defendant. Civil Judicial Statistics, 1870, xi. 
settlement-represented here by percent of cases tried-is lower in the rural county.

Figure 5 indicates that the decline in the rate of trials has not been continuous; it rose briefly in San Benito in 1910, sharply in Alameda in 1930. This pattern resembles that of the case disposition statistics. It was in 1930 that automobile accident cases first appeared in the data in substantial numbers. In Alameda, in 1930 , these cases were brought to trial more often than they were

TABLE 8. TRIALS \& HEARINGS HELD-BY TYPE

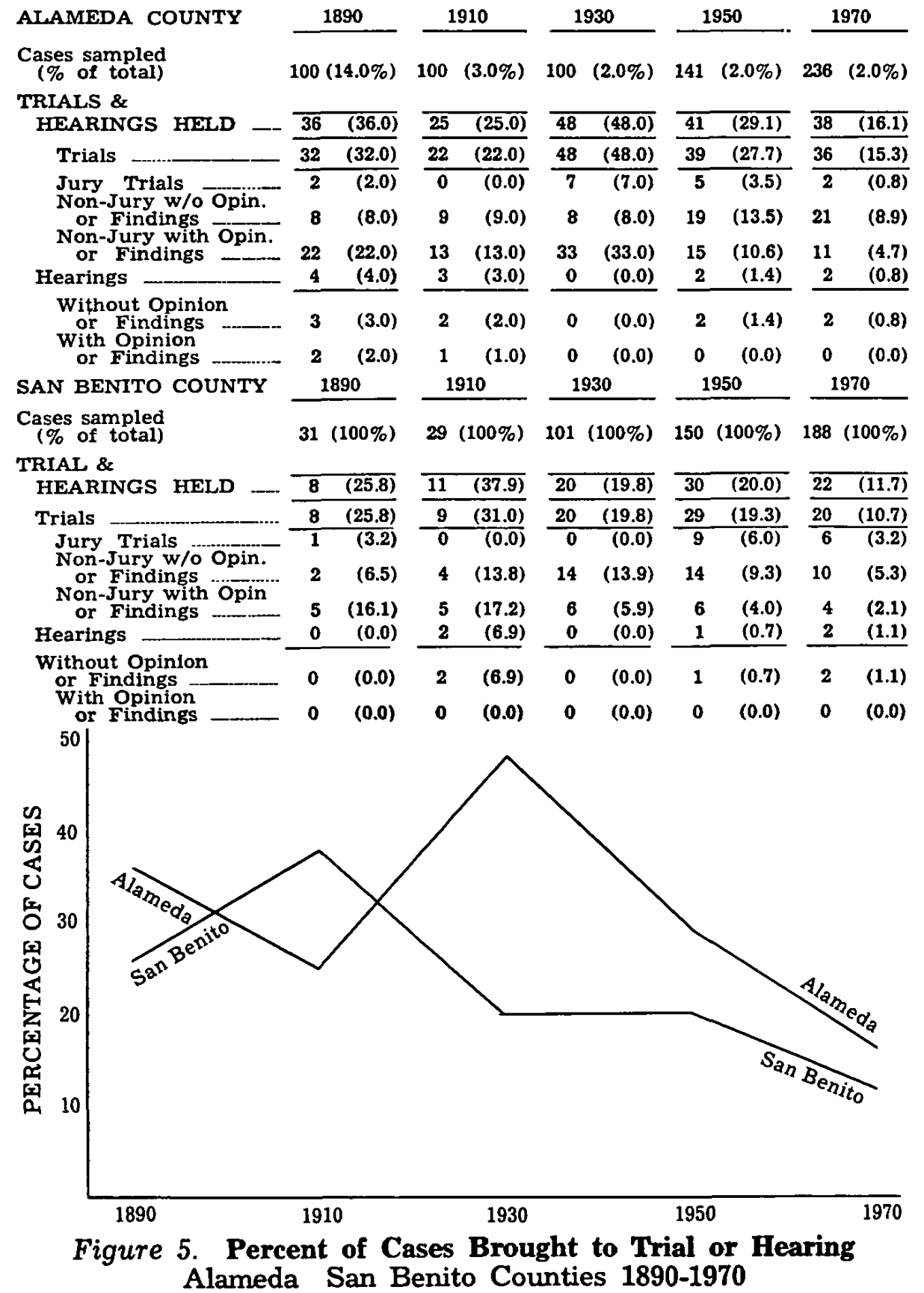


settled out of court; today less than one in ten is brought to trial there (Figure 6). Auto accident cases, however do not account completely for the sharp rise in trials in 1930; this remains, for the present, unexplained.

\section{E. Percent of Trials With Formal Opinions}

A rough indicator of the extent of dispute settlement by courts is the proportion of cases tried in which the court writes a formal opinion, or makes formal findings of fact or law. The incidence of such cases is quite similar to the incidence of trials themselves, as shown in Table 8 and Figure 7. With the exception of Alameda in 1930, formal opinions or findings in non-jury trials have declined steadily in both counties. In 1890, in both counties, judges made such opinions or findings in over $70 \%$ of non-jury trials. Today they are made in only $34 \%$ of such cases in Alameda and 29\% in San Benito (the change from 1890 is significant at the $.4 \%$ level for Alameda, and the $.6 \%$ level for San Benito). Courts feel less necessity to justify their actions formally, perhaps because of the increased routinization of their work. Again, differences between the two counties are small; if anything, the rural court works in a slightly more perfunctory way.

\section{F. Costs of Litigation-Time and Delay}

Delays and costs may be important factors that act to discourage litigation in modern courts. Formal litigation today is

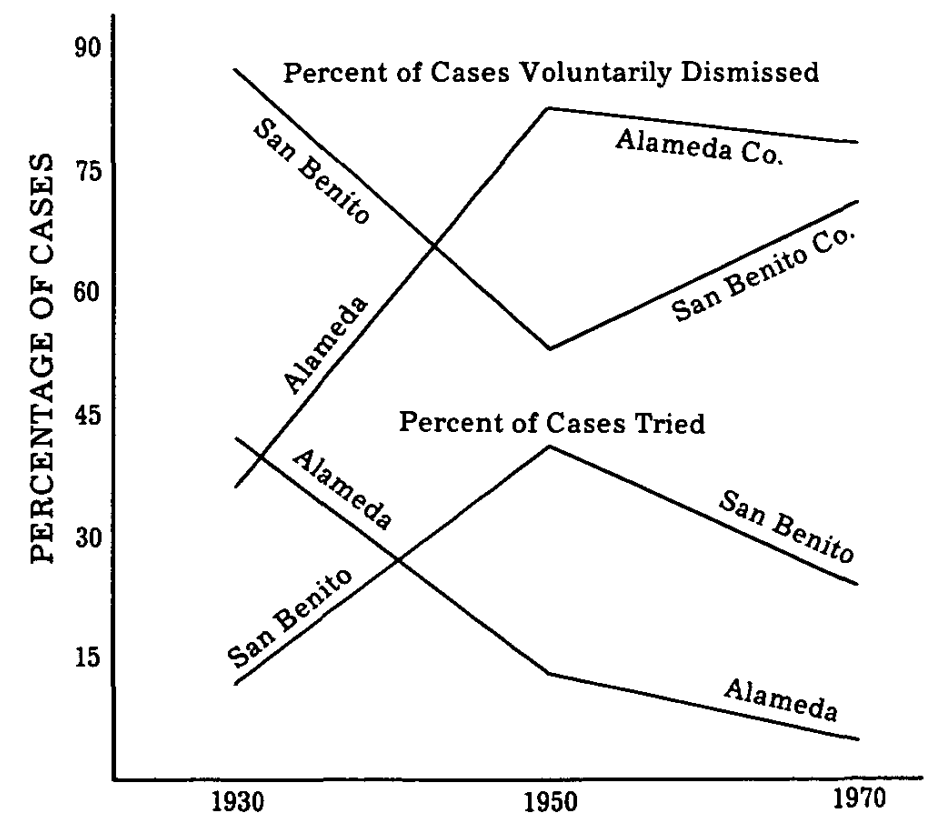

Figure 6. Auto Accident Cases-Percent Tried and Percent Voluntarily Dismissed Alameda \& San Benito Counties 1930-1970 


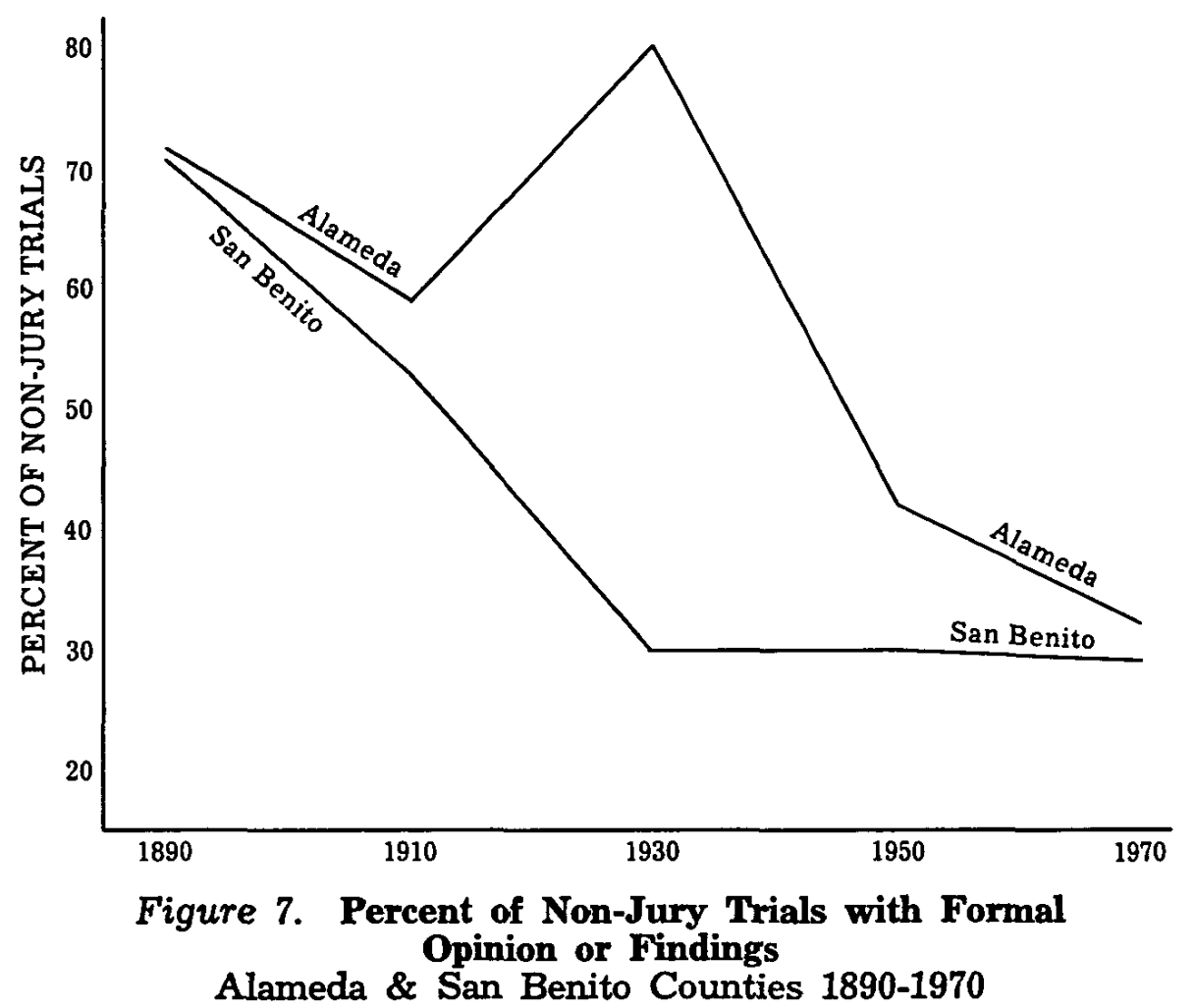

much slower than before (Tables 9 and 10, Figures 8 and 9)despite the increase in routinization of procedures and results. Delays are greater in the densely populated county of Alameda than in San Benito (three-month final disposition difference between counties; significant at the $.1 \%$ level). In $1890,44 \%$ of the cases in Alameda and 52\% of the cases in San Benito reached their final outcome within three months after filing. In 1970, in Alameda, only $9 \%$ of the cases now reach such an outcome (the difference is significant at the $1 \%$ level); in San Benito, only $26 \%$ (significant at the $2 \%$ level) are cleared from the docket within three months. Most San Benito cases take between six months and a year to reach their final outcomes; in Alameda delays up to one to two years are more frequent. Delays are particularly great for cases which go to trial (Table 11, Figure 10). In $1890,72 \%$ of such cases in Alameda were tried within six months after filing. In 1970, only $13 \%$ were brought to trial within six months (significant at the $.1 \%$ level). The actual trials also take longer (Table 12). Only $6.1 \%$ of the trials in Alameda took longer than one day in 1890 . Today, $27 \%$ of the Alameda trials-63\% of San Benito trials-take longer than one day. 


\section{G. Volume of Litigation}

Studies in a number of counties suggest an inverse relationship between economic growth and volume of formal litigation. ${ }^{\mathbf{3}}$ That is, highly developed economic systems do not show growth in their litigation rates; on the contrary, rates tend to stabilize or decline in the face of rapid economic growth.

\section{TABLE 9. PERCENT OF CASES REACHING INITAL DISPOSITION WITHIN SPECIFED TIME PERIODS}

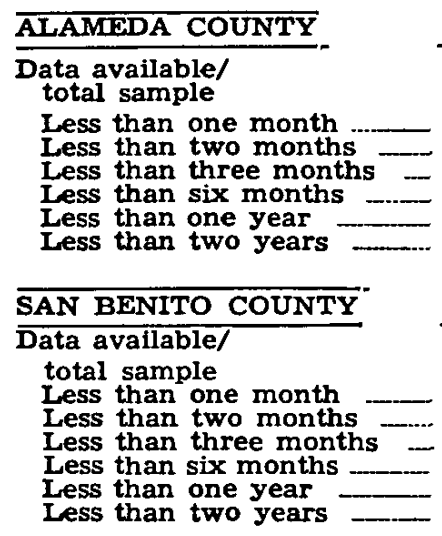

\begin{tabular}{c}
1890 \\
\hline$(91 / 100)$ \\
$23.1 \%$ \\
41.8 \\
47.3 \\
64.8 \\
75.8 \\
89.0
\end{tabular}
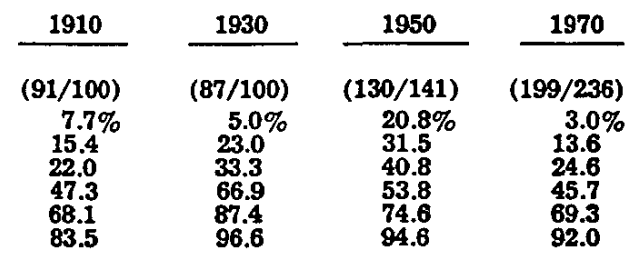

1890

\begin{tabular}{c}
1910 \\
\hline \\
$(22 / 29)$ \\
$31.8 \%$ \\
45.5 \\
63.6 \\
72.7 \\
77.3 \\
100.0
\end{tabular}

\begin{tabular}{c}
1930 \\
\hline$(68 / 101)$ \\
$35.3 \%$ \\
50.0 \\
54.4 \\
70.6 \\
85.3 \\
94.1
\end{tabular}

\begin{tabular}{c}
1950 \\
\hline$(112 / 150)$ \\
$30.4 \%$ \\
43.8 \\
54.5 \\
72.3 \\
88.4 \\
96.4
\end{tabular}

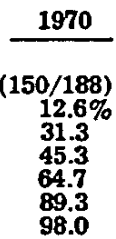

\section{TABLE 10. PERCENT OF CASES REACHING FINAL DISPOSITION WITHIN SPECIFIED TIME PERIODS}

ALAMEDA COUNTY
Data available/
total sample
Less than one month
Less than two months
Less than three months
Less than six months
Less than one year
Less than two years
SAN BENTTO COUNTY
Data available/
total sample
Less than one month
Less than two months
Less than three months
Less than six months
Less than one year
Less than two years

\begin{tabular}{l}
1890 \\
\hline$(91 / 100)$ \\
$18.7 \%$ \\
35.2 \\
44.0 \\
60.4 \\
73.6 \\
85.7 \\
\\
1890 \\
\hline \\
$(23 / 31)$ \\
$30.4 \%$ \\
39.1 \\
52.2 \\
69.6 \\
95.7 \\
95.7
\end{tabular}

\begin{tabular}{c}
1910 \\
\hline$(90 / 100)$ \\
$6.7 \%$ \\
11.1 \\
14.4 \\
34.4 \\
53.3 \\
75.6 \\
\\
1910 \\
\hline \\
$(21 / 29)$ \\
$14.3 \%$ \\
28.6 \\
33.3 \\
47.6 \\
47.6 \\
95.2
\end{tabular}

\begin{tabular}{c}
1930 \\
\hline$(87 / 100)$ \\
$5.7 \%$ \\
10.3 \\
18.4 \\
42.5 \\
65.5 \\
89.7 \\
\\
1930 \\
\hline $68 / 101)$ \\
$29.4 \%$ \\
39.7 \\
44.1 \\
55.9 \\
69.1 \\
88.2
\end{tabular}

\begin{tabular}{c}
1950 \\
\hline$(124 / 141)$ \\
$8.1 \%$ \\
13.7 \\
18.5 \\
28.2 \\
46.0 \\
79.8 \\
\\
1950 \\
\hline$(109 / 150)$ \\
$18.3 \%$ \\
27.5 \\
36.7 \\
49.5 \\
60.6 \\
84.4
\end{tabular}

\begin{tabular}{c}
1970 \\
\hline$(193 / 236)$ \\
$2.1 \%$ \\
6.2 \\
9.3 \\
18.7 \\
53.4 \\
87.0 \\
\\
1970 \\
\hline \\
$(145 / 188)$ \\
$8.1 \%$ \\
19.6 \\
26.4 \\
39.9 \\
82.4 \\
85.3
\end{tabular}

33. See the important work of José Juan Toharia, Cambio Social y Vida Juridica en España, 1900-1970 (1974); a study of the volume of civil litigation at first instance in Sweden and Denmark, between 1930 and 1970 , showed similar results. In Sweden, the volume actually decreased; in Denmark, litigation grew in absolute numbers, but not in proportion to the population. Britt-Mari P. Blegvad, P.O. Bolding, Ole Lando, Arbitration as a Means of Solving Conflicts 103-105 (1973). The rate of litigation has been static or declining in England, too, since about the turn of the century. Friedman, supra, note 2. Findings similar to Toharia's are reported- by Carlos José Gutierrez, in a study of Costa Rican litigation, as yet unpublished. 
TABLE 11. PERCENT OF CASES REACHING TRIAL WITHIN SPECIFIED TIME PERIODS
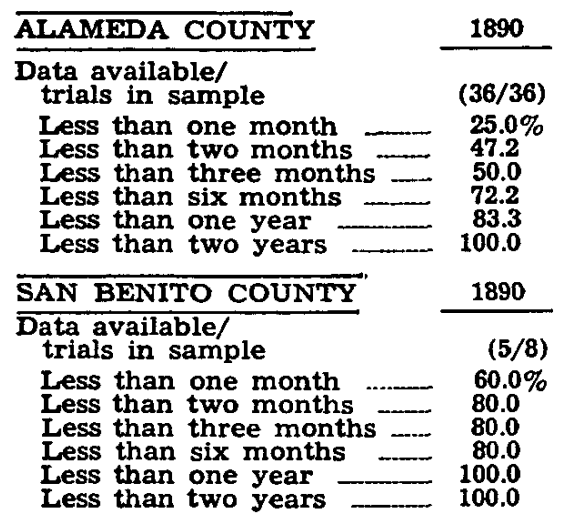

\begin{tabular}{l}
1910 \\
\hline$(24 / 25)$ \\
$12.5 \%$ \\
12.5 \\
20.8 \\
41.7 \\
54.2 \\
91.7 \\
\\
1910 \\
\hline \\
$(11 / 11)$ \\
$27.3 \%$ \\
36.4 \\
54.5 \\
54.5 \\
63.6 \\
100.0
\end{tabular}

\begin{tabular}{c}
1930 \\
\hline$(48 / 48)$ \\
$2.1 \%$ \\
14.6 \\
22.9 \\
66.7 \\
83.3 \\
95.8 \\
1930 \\
\hline \\
$(20 / 20)$ \\
$28.6 \%$ \\
33.3 \\
42.9 \\
66.7 \\
81.0 \\
95.2
\end{tabular}

\begin{tabular}{lrr}
1950 & & 1970 \\
$(37 / 40)$ & & $(38 / 38)$ \\
$24.3 \%$ & & $5.3 \%$ \\
32.4 & & 7.9 \\
40.5 & & 7.9 \\
48.6 & & 13.2 \\
78.4 & & 50.0 \\
94.6 & & 84.2 \\
& & \\
1950 & & 1970 \\
\hline & & \\
$(27 / 30)$ & & $(20 / 22)$ \\
$11.1 \%$ & & $5.0 \%$ \\
18.5 & & 15.0 \\
29.6 & & 25.0 \\
66.7 & & 60.0 \\
81.5 & & 85.0 \\
96.3 & & 100.0
\end{tabular}

TABLE 12. DURATION OF TRIALS

\begin{tabular}{|c|c|c|c|c|c|}
\hline$\overline{\text { ALAMEDA COUNTY }}$ & 1890 & 1910 & 1930 & 1950 & 1970 \\
\hline $\begin{array}{l}\text { Data available/ } \\
\text { trials in sample } \\
\text { One day or less } \\
\text { More than one day - }\end{array}$ & $31_{2}^{(33 / 36)}(93.9)$ & $\begin{array}{cc}(19 / 25) \\
16 & (84.2) \\
3 & (15.8)\end{array}$ & $\begin{array}{c}(38 / 48) \\
24^{(63.2)} \\
14 \quad(36.8)\end{array}$ & $\begin{array}{c}(33 / 40) \\
22 \\
11 \quad(66.7) \\
11\end{array}$ & $\begin{array}{ll} & (37 / 38) \\
27 & (73.0) \\
10 & (27.0)\end{array}$ \\
\hline$\overline{\text { SAN BENTTO COUNTY }}$ & 1890 & 1910 & 1930 & 1950 & 1970 \\
\hline $\begin{array}{l}\text { Data a } \\
\text { trials }\end{array}$ & $(1 / 8)$ & $(6 / 11)$ & $(3 / 20)$ & $(21 / 30)$ & $(11 / 22)$ \\
\hline $\begin{array}{l}\text { One day or less } \\
\text { More than one day }\end{array}$ & $\begin{array}{lr}1 & (100.0) \\
0 & (0.0)\end{array}$ & $\begin{array}{ll}5 & (83.3) \\
1 & (16.7)\end{array}$ & $\begin{array}{lr}3 & (100.0) \\
0 & (0.0)\end{array}$ & $\begin{array}{ll}11 & (52.4) \\
10 & (47.6)\end{array}$ & $\begin{array}{ll}4 & (36.4) \\
7 & (63.6)\end{array}$ \\
\hline
\end{tabular}

Why should this be so? The idea is that formal court processes are slow, expensive, technical. Court process is, from the economic standpoint, inefficient; and society will take no steps to encourage it for ordinary civil disputes. That formal court processes are inefficient and irrelevant to economic life, is quite consistent with our data. But it is not so clear that the two counties confirm the prediction that litigation declines as an economy develops. The rate of cases per 1,000 population in the two counties was shown in Table 2. A number of interesting facts emerge from this table. One is the convergence of the counties. In 1890, urban Alameda was more litigious than rural San Benito; differences today are very small.

Compared to 1890 , both counties show an apparent rise in cases per 1,000 population. But the rate in Alameda in 1910 was higher than it is today; and San Benito's ratio declined slightly between 1950 and 1970. And the figures are too crude to be used as indicators of litigation rates. For one thing, they do not take into account either the federal courts or the inferior trial courts. For another thing, they do not take into account the nature of the cases litigated. Before we can speak of "litigation rates" we must define litigation: is an uncontested divorce "litigation?" 
Friedman \& Percival / A TALE OF TWO COURTS
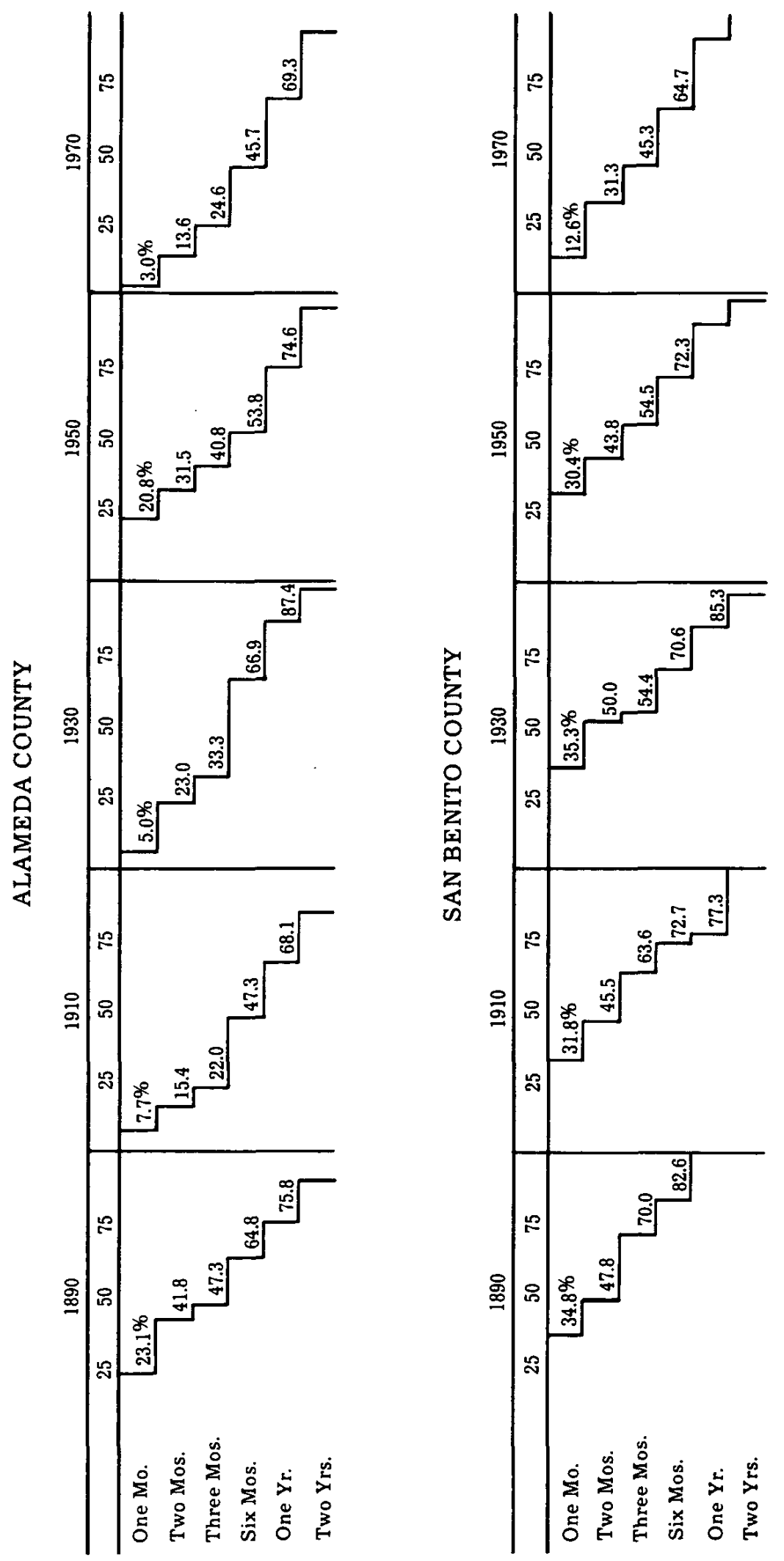

Figure 8. Time from Filing to Initial Disposition Alameda \& San Benito Counties 1890-1970 


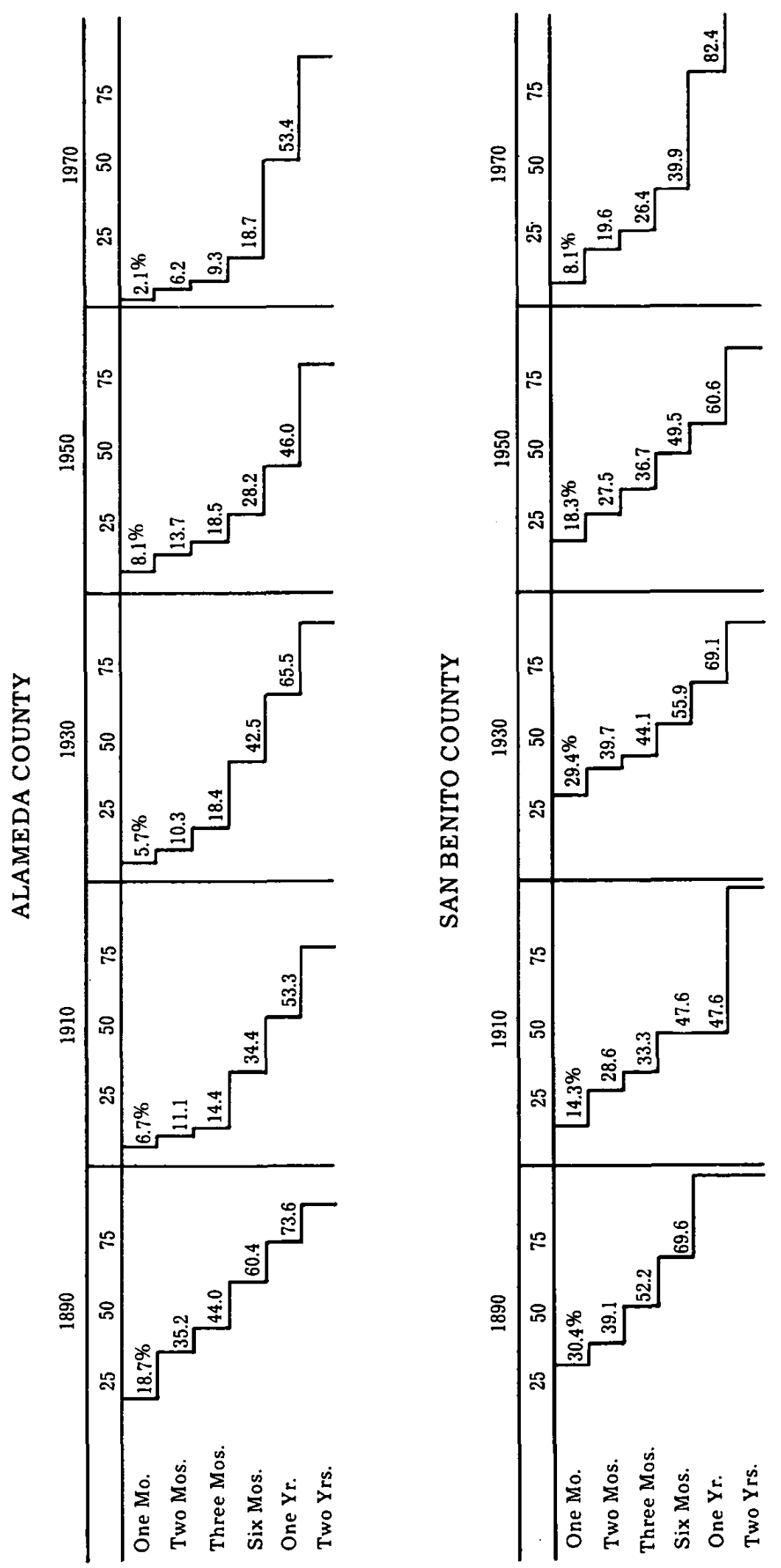

Figure 9. Time from Filing to Final Disposition Alameda \& San Benito Counties 1890-1970 
Friedman \& Percival / A TALE OF TWO COURTS

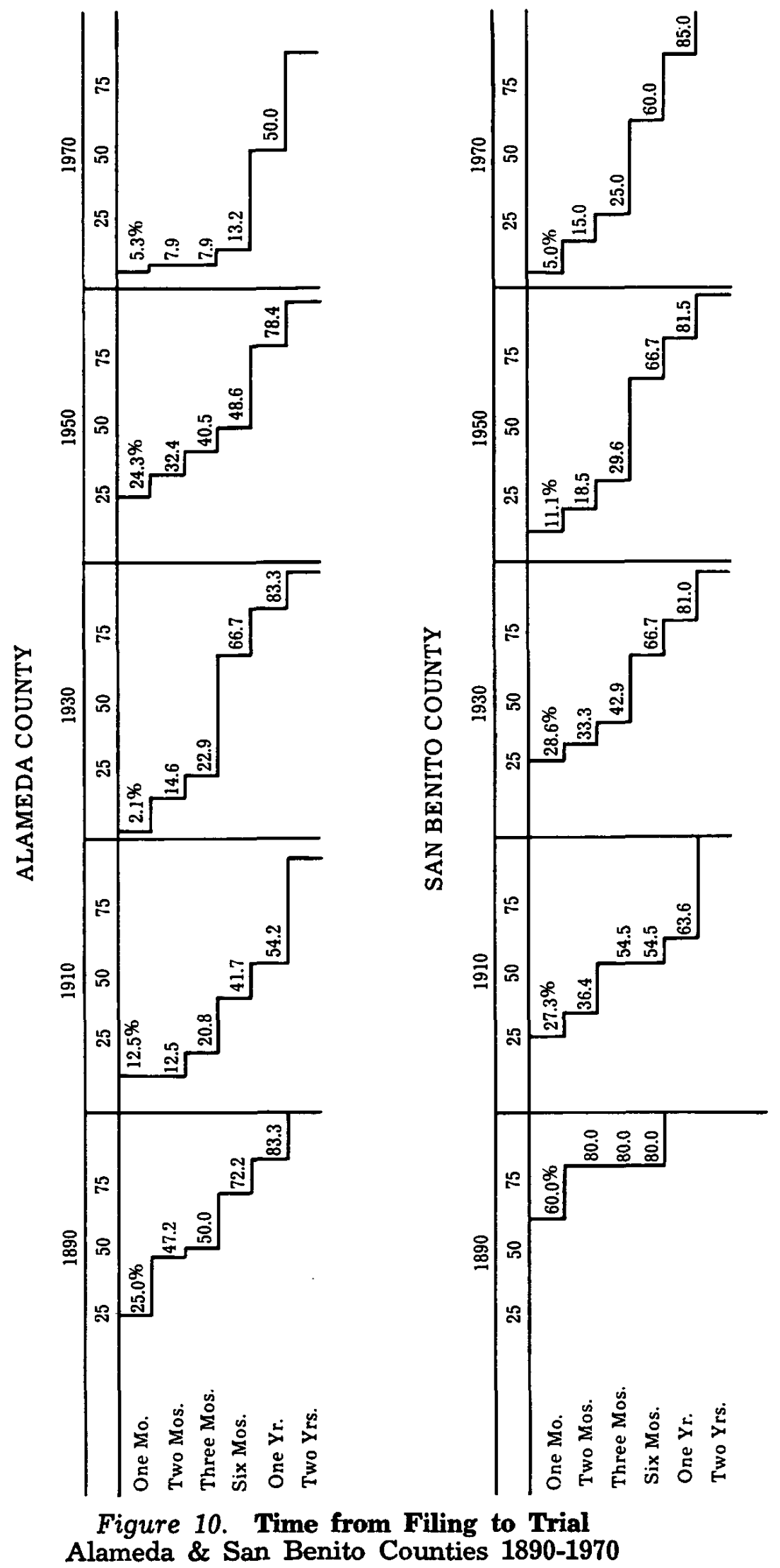


To test the hypothesis of declining litigation, we would really need some valid measure of dispute settlement, for all courts, in a community. "Litigation" would mean a proceeding containing elements of dispute, that were not resolved before one party filed a complaint, or perhaps not resolved without the intervention of a judge. Perhaps such a "true" rate would show a decline since 1890; but our figures do not permit us the luxury of a guess.

\section{CONCLUSION}

Quantitative indicators of court performances in these two counties confirm one general hypothesis: the dispute settlement function in the courts is declining. ${ }^{34}$ In general, the trial courts today perform routine administration; dispute settlement has steadily shrunk as a proportion of their caseload. Most cases today are quite routine. In 1890, a higher percentage of cases involved genuine disputes, and the work of the courts was on the whole less stereotyped. The rate of uncontested judgments has multiplied while the incidence of contested judgments has fallen. A smaller percentage of cases are brought to trial today, and courts issue formal opinions or findings in far fewer cases. Court delays have significantly lengthened.

What factors account for the routinization of the work of modern courts? One possibility is that uncertainty-a prime breeder of litigation-has declined in the law; that rules are more "settled" than in 1890. Some kinds of dispute (over land titles for example) have been largely resolved, or reduced to order by new social arrangements, such as the use of title insurance, and improvement in county record-keeping. But there is no easy way to measure this factor in the aggregate. Our assumption is that some areas of law do become "settled;" but as they do, new uncertainties replace old ones. Land titles were less chaotic in 1930 than in 1890; but as this problem faded, the automobile accident more than replaced it, creating a new and complex field of law.

34. Are these results specific to California? There is no reason to believe that they are. A spot check was made of records of Camden County, New Jersey, for the years 1892 and 1966. The records of this county show more or less the same progression. In the earlier year contract and property cases predominate; tort cases are rare. This can be seen both in the records of the Camden County trial courts, and in records of New Jersey circuit court judgments, on file in Trenton, New Jersey. By 1970, the pattern of litigation had come to resemble that of the two California counties. Family law cases are handled by separate chancery courts in New Jersey; such cases rose from a miniscule number to a dominant position in the percentage of cases decided on the trial court level in New Jersey. Time did not, however, permit comparison of urban and rural courts in New Jersey. Replication of this study in other parts of the country would be useful. 
For another possible explanation, one may point to factors associated with urbanization and the particular brand of economic development that has occurred in the United States. The population in 1970 is mobile and rootless. Overwhelmingly, people live in metropolitan areas. They deal primarily with strangers. The ordered social relations of small towns and traditional courts-a world of face to face relations-has vanished.

In this light, we might expect the modern court in San Benito to resemble its 1890 ancestor, and traditional courts, more closely than we would expect of the Alameda court. Surprisingly, however, the data of 1970 do not show much difference between the counties. On the contrary, San Benito's courts play, if anything, a more routinized role than the courts in urban Alameda. In San Benito, more cases involve routine matters, a larger proportion are uncontested, fewer are brought to trial, and courts more rarely issue formal opinions or findings.

There is a general assumption in the literature that "modernization" brings about a general shift from social-harmony litigation to a more formal style of dispute-settlement. Our data suggests a rather different kind of evolution. To be sure, in 1890 it was already true that precious little of the work of the court conformed to the social harmony style. That had perhaps already virtually vanished in the United States, unless one were to find it in the justice courts, which is doubtful. Did it ever exist? The records of colonial courts suggest that at the very dawn of American history there were institutions that came closer to the anthropologists' model. ${ }^{35}$ But by 1890, the Superior Court of Alameda was already an urban court; and as for San Benito, while it was a small community, it was hardly a tightly-knit, traditional community. On the contrary, it was a raw and new community-a community of recent arrivals, transients, strangers. $^{36}$ If anything, it is more of a face-to-face community today; and yet the social harmony style is even more absent.

The evolution, then, does not go from social harmony to legalistic style, and find a resting point. Rather, dispute settlement vanishes completely from the courts; it is replaced by routine administration. Whether the legalistic style was an intermediate phase, or whether the development was directly from social

35. For pictures of these courts at work, see Joseph H. Smith, Colonial Justice in Western Massachusetts (1639-1702): The Pynchon Court Record (1961); Paul M. McCain, The County in North Co,rolina before 1750 (1954).

36. See Friedman, supra, note 25. 
harmony style to routine, our data does not allow us to state with confidence.

Our evidence shows, then, that in the two California courtsone sitting in a bustling urban metropolis, the other not-the dispute settlement function has shriveled to almost nothing; the routine administrative function has become predominant.

This seems on the surface rather curious. Certainly, disputes still arise in society, and they probably must be settled. Yet for some reason, they are not settled in court. Of course, it is theoretically possible that fewer disputes go to court than in an earlier period because the number of disputes has fallen. We have no way to measure the number of disputes that might go to court, if court were costless and freely accessible. Nor do we have any information about the relative number of disputes in San Benito County, compared to Alameda, now or in any other period. It is barely possible that, when genuine disputes do occur in San Benito, a larger proportion of them may actually be taken to court than in Alameda. But there is no obvious reason why the number of actual "disputes" should be so low in the two counties; and the most likely assumption is that the court itselfits style, its mode of operation-discourages its use for dispute settlement, rather than that the number of issues or disputes has declined.

Apparently, litigation is not worthwhile, for the potential litigant; it is too costly, in other words; "Costs" may mean dollar costs. Delays and technicalities are also costly, because of the disruption and expense they may inflict, and the uncertainties they may introduce into outcomes. All of these costs in fact did rise during the 19th century, although the data are fragmentary. As costs rise, so does the threshold at which litigation becomes worthwhile.

But this pushes our inquiry back one step; it does not answer the basic question. If courts have become too "costly," why has society permitted this to happen? Why have there not been arrangements to keep the dispute settlement function of courts alive, and healthy and productive? Why has a situation been allowed to develop in which full scale court proceedings on the whole move slowly, cost a great deal, and proceed by rules that are a closed book to the average man-indeed, to the average businessman? Over the last two centuries, the use of courts for dispute settlement seems to have declined, while all other economic indicators in society have risen. Does this make sense? 


\section{A. Law and Development}

Let us, for simplicity, assume economic growth as a goal widely shared in early nineteenth century American society. ${ }^{37}$ How could legal process contribute to this end? First of all, it was necessary to dismantle restrictions that restrained the free flow of commerce. Second, new legal arrangements might be instituted or encouraged that would stimulate trade and manufacture. A flourishing economy, a growing economy is an economy of increasing volume. The more of society's goods traded on the market, the better; the higher the turnover, the better.

The economy, then, was to be left as free as possible, not for its own sake, but because free trade would foster prosperity. Business, left to its own devices, would develop tools-forms and techniques-that permitted and encouraged rapid trade. Such forms would be highly standard; they would permit rapid, routine, trouble-free use, as much as was humanly possible. A vigorous market is one in which people absorb losses in the short run, and continue to trade. They do not break off commercial relationships in the midst of a competitive situation, nor do they funnel transactions through courts. Any legal agency which exercises discretion and is careful, slow and individuating, cannot help but interrupt the flow of trade. It is not healthy, then, for the economy, unless parties stay out of court except as a last resort.

Hence, costs are permitted to rise. No invisible cartel raises costs, but costs go up, and they are allowed to; there is little countervailing subsidy. Ordinary disputes, between members of the middle class, slowly drain out of the system. Business also tends to avoid the courts. ${ }^{38}$ Business can afford to litigate, but does not welcome the disruptiveness of litigation. For business, too, legal norms (especially procedural ones) disappoint legitimate expectations. This formalization is a cost which society has also allowed to rise, as lawyers professionalize, courts conceptualize, and the law becomes more "scientific."

Hence, too, the relative decline in litigation, although, as we have seen, this is not so easy to attest in our two courts. One must remember that the decline in disputed proceedings in court does not mean that "the law" (in a broader sense) is of declin-

37. J. Willard Hurst, Law and the Conditions of Freedom in the 19th Century United States (1964); Lawrence M. Friedman, A History of American Law 157-58 (1973); Harry N. Scheiber, Ohio Canal Era, A Case Study of Government and the Economy, 1820-1861 (1969).

38. See Stewart Macaulay, "Non-Contractual Relations in Business: A Preliminary Study," 28 Am. Soc. Rev. 55 (1963). 
ing importance in a developing country; quite the contrary. As the economy expands, so does the use of legal instruments: contracts, checks, deeds, articles of incorporation, wills, mortgages. The number of transactions which take legal form increases more rapidly than the population. But this does not mean more "trials" and more use of formal courts to "settle disputes." In modern society, most transactions are private, that is, they take place without the intervention of the state. ${ }^{39}$ Thousands of other transactions use the courts, but only in a routine wayto collect debts, legitimize status, and so on.

Routinization, then, accompanies a lowering of the public demand for settlement of disputes in formal courts. Much of the remaining docket hangs on from sheer necessity. One must go to court to win legal freedom to remarry, for example. It is a routine but necessary step. For the rest, ordinary people are deterred by the cost, the torpor, the technicality of court proceedings. Businessmen prefer to handle matters themselves, or go to arbitration, which is perhaps less disruptive, and where an arbitrator is more likely than a judge to understand the issues, as businessmen define them. Administrative bodies (zoning boards, workmen's compensation boards) settle many others of society's disputes.

In short, the dispute-settlement trial becomes rarer and rarer. The court system does not expand; the number of judges remains more or less static. The system is rationalized and "improved;" but it remains foreign to the average potential litigant. At the trial level, formal court systems gradually lose their share of dispute settlement cases. Their work becomes, in large part, routine administration.

\section{B. City and Country}

The most surprising result of the study, however, is the striking similarity between the two counties. San Benito is small, and the population is thin. In Oakland, one can talk about "crowded" rity courts;" but certainly not in Hollister. There is less delay in San Benito, and the court is not rushed or overburdened. Yet little of consequence takes place in court. San Benito is still a small society; yet the main function of its Superior Court is to rubber stamp petitions for dissolution of marriage.

39. These private transactions are affected by law; they make use of formalities specifically validated by positive law, or they depend on the advice or consent of a lawyer or notary. 
This fact allows us to reject the hypothesis that routinization is to be explained by "industrialization" or "urbanization." There is little industry in San Benito, and no real city. But San Benito is part of an urban, industrial society. It is not isolated from modern influence. It is an hour's drive from the Bay Area megalopolis. The mass media lace all communities together; people in Hollister watch the same programs, read much the same news, eat much the same food, as people elsewhere in the country. They are part of a common culture.

It is a culture in which there seems to be factors in the structure of courts-and, more fundamentally, in social attitudeswhich have combined to make "going to court" obsolete, as part of the normal life-cycle of dispute settlement. We cannot identify these factors precisely. But their influence on the work of the courts is far more powerful than the gross demographic differences between "cities" and "small towns."

Whatever the causes, the figures for these two courts show a general movement from dispute settlement to routine administration over the past century. We believe this is a national phenomenon, too. It is a development which may pose problems for society. No doubt courts are still very useful, in a number of ways; but they are almost totally unused by ordinary individuals to resolve personal problems. The overwhelming majority of business disputes also avoid the courts. Citizen and businessmen alike either seek out some other agency, or make use of resources within the family, group, or trade association-or, as is frequently the case, handle the matter entirely on their own. ${ }^{40}$ The judicial system is often elaborately praised. The praise rings hollow if, as it appears, factors at work militate against the use of the system. We must ask, what are the institutions that have replaced the courts, and how do they operate? And, where no institutions have appeared to fill what may well be a gap, we must ask, what has society gained and lost, as an ancient structure of decision passes into history?

40. That is, parties or potential parties may choose to make use of "rival" institutions, such as arbitration. See Britt-Mari P. Blegvad, et. al., supra, note 33, or what William Felstiner calls "avoidance." Avoidance is a technique of withdrawal (for example, "consumers switching their trade from one retail merchant to another after a dispute") or it may take the form of "lumping it," where "the salience of the dispute is reduced not so much by limiting the contacts between the disputants, but by ignoring the dispute, by declining to take any or much action in response to the controversy." William L.F. Felstiner, "Influences of Social Organization on Dispute Processing," 9 Law \& Society Review 63, 76, 81 (1974); see also Richard L. Abel, "A Comparative Theory of Dispute Institutions in Society," 8 Law \& Society Review 217 (1974). 
Heinonline -- 10 Law \& Soc'y Rev. 302 1975-1976 